\title{
Stem and soil nitrous oxide fluxes from rainforest and cacao agroforest on highly weathered soils in the Congo Basin
}

\author{
Najeeb Al-Amin Iddris ${ }^{1}$, Marife D. Corre ${ }^{1}$, Martin Yemefack ${ }^{2, a}$, Oliver van Straaten ${ }^{1, b}$, and Edzo Veldkamp ${ }^{1}$ \\ ${ }^{1}$ Soil Science of Tropical and Subtropical Ecosystems, University of Göttingen, 37077 Göttingen, Germany \\ ${ }^{2}$ International Institute of Tropical Agriculture, Yaoundé, Cameroon \\ ${ }^{a}$ now at: Sustainable Tropical Solutions (STS), Yaoundé, Cameroon \\ b now at: Northwest German Forest Research Institute, 37079 Göttingen, Germany
}

Correspondence: Najeeb Al-Amin Iddris (niddris@gwdg.de)

Received: 9 May 2020 - Discussion started: 25 May 2020

Revised: 11 September 2020 - Accepted: 25 September 2020 - Published: 10 November 2020

\begin{abstract}
Although tree stems act as conduits for greenhouse gases (GHGs) produced in the soil, the magnitudes of tree contributions to total (soil + stem) nitrous oxide $\left(\mathrm{N}_{2} \mathrm{O}\right)$ emissions from tropical rainforests on heavily weathered soils remain unknown. Moreover, soil GHG fluxes are largely understudied in African rainforests, and the effects of land-use change on these gases are identified as an important research gap in the global GHG budget. In this study, we quantified the changes in stem and soil $\mathrm{N}_{2} \mathrm{O}$ fluxes with forest conversion to cacao agroforestry. Stem and soil $\mathrm{N}_{2} \mathrm{O}$ fluxes were measured monthly for a year (2017-2018) in four replicate plots per land use at three sites across central and southern Cameroon. Tree stems consistently emitted $\mathrm{N}_{2} \mathrm{O}$ throughout the measurement period and were positively correlated with soil $\mathrm{N}_{2} \mathrm{O}$ fluxes. ${ }^{15} \mathrm{~N}$-isotope tracing from soil mineral $\mathrm{N}$ to stem-emitted ${ }^{15} \mathrm{~N}_{2} \mathrm{O}$ and correlations between temporal patterns of stem $\mathrm{N}_{2} \mathrm{O}$ emissions, soil-air $\mathrm{N}_{2} \mathrm{O}$ concentration, soil $\mathrm{N}_{2} \mathrm{O}$ emissions and vapour pressure deficit suggest that $\mathrm{N}_{2} \mathrm{O}$ emitted by the stems originated predominantly from $\mathrm{N}_{2} \mathrm{O}$ produced in the soil. Forest conversion to extensively managed, mature ( $>20$ years old) cacao agroforestry had no effect on stem and soil $\mathrm{N}_{2} \mathrm{O}$ fluxes. The annual total $\mathrm{N}_{2} \mathrm{O}$ emissions were $1.55 \pm 0.20 \mathrm{~kg} \mathrm{~N} \mathrm{ha}^{-1} \mathrm{yr}^{-1}$ from the forest and $1.15 \pm 0.10 \mathrm{~kg} \mathrm{Nha}^{-1} \mathrm{yr}^{-1}$ from cacao agroforestry, with tree $\mathrm{N}_{2} \mathrm{O}$ emissions contributing $11 \%$ to $38 \%$ for forests and $8 \%$ to $15 \%$ for cacao agroforestry. These substantial contributions of tree stems to total $\mathrm{N}_{2} \mathrm{O}$ emissions highlight the importance of including tree-mediated fluxes in ecosystem GHG budgets. Taking into account that our study sites' biophysical characteristics represented two-
\end{abstract}

thirds of the humid rainforests in the Congo Basin, we estimated a total $\mathrm{N}_{2} \mathrm{O}$ source strength for this region of $0.18 \pm 0.05 \mathrm{Tg} \mathrm{N}_{2} \mathrm{O}-\mathrm{N} \mathrm{yr}^{-1}$.

\section{Introduction}

The trace gas nitrous oxide $\left(\mathrm{N}_{2} \mathrm{O}\right)$ has become the main stratospheric ozone-depleting substance produced by human activities (Ravishankara et al., 2009) and is after carbon dioxide and methane $\left(\mathrm{CH}_{4}\right)$ the most important anthropogenic greenhouse gas (GHG) (Denman et al., 2007). Humid tropical soils are considered one of the most important global $\mathrm{N}_{2} \mathrm{O}$ sources (Denman et al., 2007; Werner et al., 2007a), with tropical rainforests alone estimated to contribute between 0.9 and $4.5 \mathrm{Tg} \mathrm{N}_{2} \mathrm{O}-\mathrm{N} \mathrm{yr}^{-1}$ to the global $\mathrm{N}_{2} \mathrm{O}$ source of about $16 \mathrm{Tg} \mathrm{N}_{2} \mathrm{O}-\mathrm{N} \mathrm{yr}^{-1}$ (Bouwman et al., 1995; Breuer et al., 2000; Werner et al., 2007a). However, ground-based, bottom-up $\mathrm{N}_{2} \mathrm{O}$ emission estimates appear to be in stark contrast to the high emissions estimated from top-down approaches such as modelling and global $\mathrm{N}_{2} \mathrm{O}$ atmospheric inversions (Huang et al., 2008; Thompson et al., 2014). Nevertheless, there exists considerable uncertainty in both approaches (Davidson and Kanter, 2014), especially for the tropics (Valentini et al., 2014). Recent studies suggest two possible reasons for large uncertainties in bottom-up approaches: "missing" emission pathways such as trees (Welch et al., 2019) and a strong geographic bias of measured $\mathrm{N}_{2} \mathrm{O}$ fluxes from tropical forests. 
Most of the studies on soil $\mathrm{N}_{2} \mathrm{O}$ fluxes from tropical ecosystems were conducted in South and Central America (Davidson and Verchot, 2000; Matson et al., 2017; Neill et al., 2005; Wolf et al., 2011), tropical Asia (Hassler et al., 2017; Purbopuspito et al., 2006; Veldkamp et al., 2008; Verchot et al., 2006; Werner et al., 2006), and Australia (Breuer et al., 2000; Kiese et al., 2003). Africa remains the continent with the fewest published field studies on soil $\mathrm{N}_{2} \mathrm{O}$ fluxes from the tropical forest biome. After the pioneering work by Serca et al. (1994), very few field studies have been conducted, most of which were either not replicated with independent plots or only with short measurement campaigns (Castaldi et al., 2013; Gütlein et al., 2018; Wanyama et al., 2018; Werner et al., 2007b). The remaining studies were based on laboratory incubations, which cannot be translated to actual field conditions. Consequently, field-based studies with sufficient spatial and temporal coverage are critical for improving the highly uncertain $\mathrm{N}_{2} \mathrm{O}$ sink and source estimates for Africa (Kim et al., 2016b; Valentini et al., 2014).

The Congo Basin is the second largest intact tropical forest in the world and constitutes one of the most important carbon (C) and biodiversity reservoirs globally. Behind the DR Congo, Cameroon is the second highest deforested country in the Congo Basin with about $75 \%$ of its forest being subject to pressure from other land uses including agroforestry (Dkamela, 2010). Conversion of forests to traditional cacao agroforestry (CAF) systems has been well documented in Cameroon (Saj et al., 2013; Sonwa et al., 2007; Zapfack et al., 2002). Presently, an estimated 400000 ha is under CAF on small family farms of approximately 1 to 3 ha (Kotto et al., 2002; Saj et al., 2013). These CAF systems are commonly established under the shade of the forests' remnant trees and are characterized by the absence of fertilizer inputs and low yields of up to $1 \mathrm{t}$ cacao beans ha ${ }^{-1}$ (Saj et al., 2013).

Changes in land use have been found to affect soil $\mathrm{N}_{2} \mathrm{O}$ emissions due to changes in soil $\mathrm{N}$ availability, vegetation and management practices such as $\mathrm{N}$ fertilization (Corre et al., 2006; Davidson and Verchot, 2000; Groffman et al., 2000; Hassler et al., 2017; Veldkamp et al., 2020). In particular, unfertilized agroforestry and agricultural systems have been found to have $\mathrm{N}_{2} \mathrm{O}$ fluxes comparable to those from the reference forests (Hassler et al., 2017), whereas $\mathrm{N}$-fertilized systems tend to have higher $\mathrm{N}_{2} \mathrm{O}$ fluxes than the previous forest due to elevated soil mineral $\mathrm{N}$ following fertilization (Verchot et al., 2006). This is in line with postulations of the conceptual hole-in-the-pipe (HIP) model, which suggests that the magnitude of $\mathrm{N}_{2} \mathrm{O}$ emissions from the soil is largely controlled first by soil $\mathrm{N}$ availability and second by soil water content (Davidson et al., 2000). A systematic comparison between a reference land use and a converted system for quantifying land-use change effects on GHG fluxes is virtually lacking for the Congo Basin and thus an important knowledge gap in the GHG budget of Africa (Valentini et al., 2014).
Tree stems have been found to act as conduits for soil $\mathrm{N}_{2} \mathrm{O}$ in wetlands, mangroves and well-drained forests (Kreuzwieser et al., 2003; Rusch and Rennenberg, 1998; Welch et al., 2019), facilitating the transport from the soil, where $\mathrm{N}_{2} \mathrm{O}$ is produced or consumed by microbial nitrification and denitrification processes, to the atmosphere. Findings of strong declines in $\mathrm{N}_{2} \mathrm{O}$ emissions with increasing stem height (Barba et al., 2019; Díaz-Pinés et al., 2016; Rusch and Rennenberg, 1998; Wen et al., 2017) suggest that $\mathrm{N}_{2} \mathrm{O}$ is mainly emitted through the stems and less likely through the leaves. Trees adapted to wetlands and mangroves have aerenchyma systems through which $\mathrm{N}_{2} \mathrm{O}$ can be transported from the soil into the tree by both gas diffusion and transpiration stream, with exchange to the atmosphere predominantly through the stem lenticels (Rusch and Rennenberg, 1998; Wen et al., 2017). However, for trees on welldrained soils, a different transport mechanism appears to be dominant: transpiration drives the xylem sap flow in which dissolved $\mathrm{N}_{2} \mathrm{O}$ is transported from the soil to the tree and emitted to the atmosphere through the stem surface and stomata (Machacova et al., 2013; Wen et al., 2017). Recent evidence shows that trees can also act as $\mathrm{N}_{2} \mathrm{O}$ sinks (Barba et al., 2019; Machacova et al., 2017), highlighting the need for further research of the stem $\mathrm{N}_{2} \mathrm{O}$ flux magnitudes and their mechanisms.

The most important soil parameters found to influence tree stem $\mathrm{N}_{2} \mathrm{O}$ fluxes include soil water content (Machacova et al., 2016; Rusch and Rennenberg, 1998), soil $\mathrm{N}_{2} \mathrm{O}$ fluxes (Díaz-Pinés et al., 2016; Wen et al., 2017), soil temperature (Machacova et al., 2013) and soil-air $\mathrm{N}_{2} \mathrm{O}$ concentration within the rooting zone (Machacova et al., 2013; Wen et al., 2017). These studies also reported environmental parameters, such as air temperature and vapour pressure deficit, to drive stem $\mathrm{N}_{2} \mathrm{O}$ fluxes due to their influence on transpiration (O'Brien et al., 2004). For temperate forests on well-drained soil, annual stem $\mathrm{N}_{2} \mathrm{O}$ fluxes have been found to contribute up to $10 \%$ of the ecosystem $\mathrm{N}_{2} \mathrm{O}$ emissions (Wen et al., 2017). However, until now, there have been no ground-based spatial extrapolation of the contribution of stem $\mathrm{N}_{2} \mathrm{O}$ emissions from tropical forests on well-drained soils. Hence, there is a need for concurrent quantifications of the contributions of stem and soil $\mathrm{N}_{2} \mathrm{O}$ fluxes so as to provide insights into the source strengths of $\mathrm{N}_{2} \mathrm{O}$ emissions from tropical African land uses and to improve estimates of $\mathrm{N}_{2} \mathrm{O}$ emissions from the region.

Our present study addresses these knowledge gaps by providing year-round measurements of stem and soil $\mathrm{N}_{2} \mathrm{O}$ fluxes from forests and converted CAF systems with spatially replicated plots in the Congo Basin as well as stem $\mathrm{N}_{2} \mathrm{O}$ fluxes of 23 tree species that have not been measured before. Our findings contribute to the much-needed improvement of GHG budget from this region. Our study aimed to (i) assess whether trees in tropical rainforests and CAF are important conduits of $\mathrm{N}_{2} \mathrm{O}$, (ii) quantify changes in soil-atmosphere $\mathrm{N}_{2} \mathrm{O}$ fluxes with forest conversion to $\mathrm{CAF}$, and (iii) determine 
the temporal and spatial controls of stem and soil $\mathrm{N}_{2} \mathrm{O}$ fluxes. We hypothesized that (i) stem and soil $\mathrm{N}_{2} \mathrm{O}$ fluxes from these extensively managed CAF systems (unfertilized and manual harvest) will be comparable to the natural forests, and (ii) the seasonal pattern of stem emissions will parallel that of soil $\mathrm{N}_{2} \mathrm{O}$ emissions, and both will have similar soil and climatic controlling factors.

\section{Materials and methods}

\subsection{Study area and experimental design}

Our study was conducted at three study sites located in southern and central Cameroon, where natural forests are predominantly converted to CAF (Sonwa et al., 2007). Sites in the southern region were located around the villages of Aloum $\left(2.813^{\circ} \mathrm{N}, 10.719^{\circ} \mathrm{E} ; 651 \mathrm{~m}\right.$ above sea level, a.s.l.) and Biba Yezoum $\left(3.158^{\circ} \mathrm{N}, 12.292^{\circ} \mathrm{E} ; 674 \mathrm{~m}\right.$ a.s.1.), and the third site was located around the village of Tomba $\left(3.931^{\circ} \mathrm{N}\right.$, $12.430^{\circ} \mathrm{E} ; 752 \mathrm{~m}$ a.s.1.) in the central region (Fig. B1 in Appendix $\mathrm{B}$ ). The mean annual air temperature across the three sites is $23.5^{\circ} \mathrm{C}$ (Climate-Data.org, 2019), and the soil temperature ranged from 21.6 to $24.4^{\circ} \mathrm{C}$ during our measurement period from May 2017 to April 2018. The study sites span an annual precipitation from $1576 \mathrm{~mm} \mathrm{yr}^{-1}$ in central Cameroon to $2064 \mathrm{~mm} \mathrm{yr}^{-1}$ in the south of Cameroon (Table A1 in Appendix A; Climate-Data.org, 2019). Precipitation occurs in a bimodal pattern, with two dry seasons ( $<120 \mathrm{~mm}$ monthly rainfall) occurring from July to August and December to February. All sites are situated on heavily weathered soils classified as Ferralsols (FAO classification; IUSS Working Group WRB, 2015). Geologically, Tomba and Biba Yezoum are underlain by middle to superior Precambrian basement rocks (metamorphic schists, phyllites and quartzites), whereas the Aloum site is situated on inferior Precambrian basement rocks (inferior gneiss and undifferentiated gneiss) (Gwanfogbe et al., 1983).

At each of the three sites, we studied two land-use systems: the reference forest and the converted CAF system. Additional information on vegetation and site characteristics is reported in Table A1. These CAF sites were established right after clearing the natural forests, where remnant forest trees were retained by farmers to provide shade for understorey cacao trees (Theobroma cacao). Cacao planting and localized weeding were all done manually using hand tools. Interviews of farm owners indicated that there had been no mineral fertilization at any of the CAF sites. The ages of the CAF since conversion varied between 22 and $\sim 45$ years.

We selected four replicate plots $(50 \mathrm{~m} \times 50 \mathrm{~m}$ each with a minimum distance of $100 \mathrm{~m}$ between plots) per land-use type within each site (Fig. B1), totalling 24 plots that were all located on relatively flat topography. Within each plot, all stems including cacao trees with a diameter at breast height $(\mathrm{DBH}) \geq 10 \mathrm{~cm}$ were identified and measured for DBH and height. We conducted $\mathrm{N}_{2} \mathrm{O}$ flux measurements and soil and meteorological parameters in the inner $40 \mathrm{~m} \times 40 \mathrm{~m}$ area within each plot to minimize edge effects. To check that soil conditions were comparable between the reference forests and converted CAF, we compared a land-use-independent soil characteristic, i.e. clay content at $30-50 \mathrm{~cm}$ depth, between these land uses at each site. Since we did not find significant differences in clay contents between the forest and CAF at each site (Table 1), we inferred that land-use types within each site had comparable initial soil characteristics prior to conversion, and any differences in $\mathrm{N}_{2} \mathrm{O}$ fluxes and soil controlling factors can be attributed to land-use conversion.

For measurements of stem $\mathrm{N}_{2} \mathrm{O}$ fluxes, we selected six cacao trees per replicate plot in the CAF and six trees representing the most dominant species within each replicate plot in the forest, based on their importance value index (IVI) (Table A2). The species IVI is a summation of the relative density, relative frequency and relative dominance of the tree species (Curtis and McIntosh, 1951). For a given species, the relative density refers to its total number of individuals in the four forest plots at each site, the relative frequency refers to its occurrence among the four forest plots and the relative dominance refers to its total basal area in the four forest plots, all expressed as percentages of all species. These 24 trees measured at each site ( 6 trees $\times 4$ forest plots) included nine species at the Aloum site, seven species at the Biba Yezoum site and 10 species at the Tomba site (species are specified in Fig. 1; Table A2). The trees were measured for stem $\mathrm{N}_{2} \mathrm{O}$ fluxes at $1.3 \mathrm{~m}$ height above the ground at monthly intervals from May 2017 to April 2018. Furthermore, we assessed the influence of tree height on stem $\mathrm{N}_{2} \mathrm{O}$ fluxes by conducting additional measurements on 16 individual trees per land use in May 2018; these trees were included in the monthly measurements but were additionally measured at three stem heights $(1.3,2.6$ and $3.9 \mathrm{~m}$ from the ground) per tree in the forest, and at two heights $(1.3$ and $2.6 \mathrm{~m})$ per tree in the CAF due to the limited height of the cacao trees.

For soil $\mathrm{N}_{2} \mathrm{O}$ flux measurements, we installed four permanent chamber bases per replicate plot which were randomly distributed within the inner $40 \mathrm{~m} \times 40 \mathrm{~m}$ area. We conducted monthly measurements of soil $\mathrm{N}_{2} \mathrm{O}$ fluxes from May 2017 to April 2018 as well as meteorological and soil variables known to control $\mathrm{N}_{2} \mathrm{O}$ emission (see below).

\subsection{Measurement of stem and soil $\mathrm{N}_{2} \mathrm{O}$ fluxes}

We measured in situ stem $\mathrm{N}_{2} \mathrm{O}$ fluxes using stem chambers made from transparent polyethylene terephthalate foil, as described by Wen et al. (2017). About 1 month prior to measurement, we applied acetic acid-free silicone sealant strips (Otto Seal ${ }^{\circledR}$ S110, Hermann Otto GmbH, Fridolfing, Germany) about $1 \mathrm{~cm}$ wide and $20 \mathrm{~cm}$ apart around the surface of the tree stems (between 1.2 and $1.4 \mathrm{~m}$ height from the ground) that stayed permanently to ensure that all the stem 
Table 1. Mean ( \pm SE, $n=4)$ soil biochemical characteristics in the top $50 \mathrm{~cm}^{\mathrm{a}}$ depth in forest and cacao agroforestry (CAF) within each site in the Congo Basin, Cameroon. Means followed by different lowercase letters indicate significant differences between land-use types within each site, and different capital letters indicate significant differences among the three sites within a land-use type (ANOVA with Tukey's honest significance difference (HSD) test or Kruskal-Wallis ANOVA with a multiple-comparison extension test at $P \leq 0.05$ ).

\begin{tabular}{|c|c|c|c|c|c|c|}
\hline \multirow{2}{*}{$\begin{array}{l}\text { Soil } \\
\text { characteristics }\end{array}$} & \multicolumn{2}{|c|}{ Aloum site } & \multicolumn{2}{|c|}{ Biba Yezoum site } & \multicolumn{2}{|c|}{ Tomba site } \\
\hline & Forest & CAF & Forest & CAF & Forest & CAF \\
\hline Clay $(30-50$ & $66.0 \pm 2.4^{\mathrm{a}, \mathrm{A}}$ & $59.3 \pm 6.1^{\mathrm{a}, \mathrm{A}}$ & $32.8 \pm 9.4^{\mathrm{a}, \mathrm{B}}$ & $39.5 \pm 0.9^{\mathrm{a}, \mathrm{B}}$ & $55.3 \pm 0.5^{\mathrm{a}, \mathrm{AB}}$ & $51.8 \pm 1.1^{\mathrm{a}, \mathrm{AB}}$ \\
\hline Bulk density $\left(\mathrm{g} \mathrm{cm}^{-3}\right)$ & $1.2 \pm 0.1^{\mathrm{a}, \mathrm{A}}$ & $1.2 \pm 0.1^{\mathrm{a}, \mathrm{A}}$ & $1.2 \pm 0.1^{\mathrm{a}, \mathrm{A}}$ & $1.2 \pm 0.1^{\mathrm{a}, \mathrm{A}}$ & $1.2 \pm 0.1^{\mathrm{a}, \mathrm{A}}$ & $1.2 \pm 0.1^{\mathrm{a}, \mathrm{A}}$ \\
\hline $\mathrm{pH}\left(1: 4 \mathrm{H}_{2} \mathrm{O}\right)$ & $3.7 \pm 0.0^{\mathrm{b}, \mathrm{A}}$ & $4.1 \pm 0.1^{\mathrm{a}, \mathrm{A}}$ & $3.7 \pm 0.1^{\mathrm{b}, \mathrm{A}}$ & $4.6 \pm 0.2^{\mathrm{a}, \mathrm{A}}$ & $3.6 \pm 0.0^{\mathrm{b}, \mathrm{A}}$ & $4.5 \pm 0.2^{\mathrm{a}, \mathrm{A}}$ \\
\hline${ }^{15} \mathrm{~N}$ natural abundance $(\% o)$ & $8.4 \pm 0.2^{\mathrm{b}, \mathrm{A}}$ & $10.2 \pm 0.1^{\mathrm{a}, \mathrm{A}}$ & $8.6 \pm 0.2^{\mathrm{a}, \mathrm{A}}$ & $9.1 \pm 0.2^{\mathrm{a}, \mathrm{B}}$ & $8.8 \pm 0.1^{\mathrm{a}, \mathrm{A}}$ & $8.8 \pm 0.1^{\mathrm{a}, \mathrm{B}}$ \\
\hline Soil organic $\mathrm{C}\left(\mathrm{kg} \mathrm{C} \mathrm{m}^{-2}\right)$ & $12.1 \pm 0.4^{\mathrm{a}, \mathrm{A}}$ & $6.7 \pm 0.2^{\mathrm{b}, \mathrm{A}}$ & $7.2 \pm 0.9^{\mathrm{a}, \mathrm{B}}$ & $5.6 \pm 0.7^{\mathrm{a}, \mathrm{A}}$ & $9.8 \pm 0.2^{\mathrm{a}, \mathrm{AB}}$ & $7.1 \pm 0.4^{\mathrm{b}, \mathrm{A}}$ \\
\hline Total N $\left(\mathrm{kg} \mathrm{N} \mathrm{m}^{-2}\right)$ & $1.1 \pm 0.1^{\mathrm{a}, \mathrm{A}}$ & $0.7 \pm 0.0^{\mathrm{b}, \mathrm{A}}$ & $0.7 \pm 0.1^{\mathrm{a}, \mathrm{A}}$ & $0.5 \pm 0.0^{\mathrm{a}, \mathrm{B}}$ & $0.9 \pm 0.0^{\mathrm{a}, \mathrm{A}}$ & $0.7 \pm 0.0^{\mathrm{b}, \mathrm{A}}$ \\
\hline $\operatorname{ECEC}^{\mathrm{b}}\left(\mathrm{mmol}_{\mathrm{c}} \mathrm{kg}^{-1}\right)$ & $57.5 \pm 3.9^{\mathrm{a}, \mathrm{A}}$ & $33.9 \pm 2.8^{\mathrm{b}, \mathrm{A}}$ & $49.1 \pm 11.3^{\mathrm{a}, \mathrm{A}}$ & $41.1 \pm 7.2^{\mathrm{a}, \mathrm{A}}$ & $58.5 \pm 2.0^{\mathrm{a}, \mathrm{A}}$ & $46.8 \pm 4.7^{\mathrm{a}, \mathrm{A}}$ \\
\hline Exch. bases ${ }^{\mathrm{b}}\left(\mathrm{mmol}_{\mathrm{c}} \mathrm{kg}^{-1}\right)$ & $3.5 \pm 0.3^{\mathrm{b}, \mathrm{B}}$ & $8.7 \pm 1.7^{\mathrm{a}, \mathrm{B}}$ & $8.5 \pm 1.1^{\mathrm{b}, \mathrm{A}}$ & $31.0 \pm 8.5^{\mathrm{a}, \mathrm{A}}$ & $9.3 \pm 0.8^{\mathrm{b}, \mathrm{A}}$ & $30.4 \pm 7.6^{\mathrm{a}, \mathrm{A}}$ \\
\hline Exchangeable $\mathrm{Al}\left(\mathrm{mmol}_{\mathrm{c}} \mathrm{kg}^{-1}\right)$ & $47.3 \pm 3.1^{\mathrm{a}, \mathrm{A}}$ & $20.9 \pm 3.5^{\mathrm{b}, \mathrm{A}}$ & $32.9 \pm 8.9^{\mathrm{a}, \mathrm{A}}$ & $5.4 \pm 1.2^{\mathrm{b}, \mathrm{B}}$ & $39.2 \pm 2.3^{\mathrm{a}, \mathrm{A}}$ & $12.3 \pm 2.7^{\mathrm{b}, \mathrm{AB}}$ \\
\hline
\end{tabular}

a Values are the depth-weighted average, except for clay content $(30-50 \mathrm{~cm})$ and stocks of soil organic $\mathrm{C}$ and total N, which are the sum of the entire $50 \mathrm{~cm}$ depth. ${ }^{\mathrm{b}}$ ECEC: effective cation exchange capacity; Exch. bases: sum of exchangeable $\mathrm{Ca}, \mathrm{Mg}, \mathrm{K}$ and $\mathrm{Na}$.
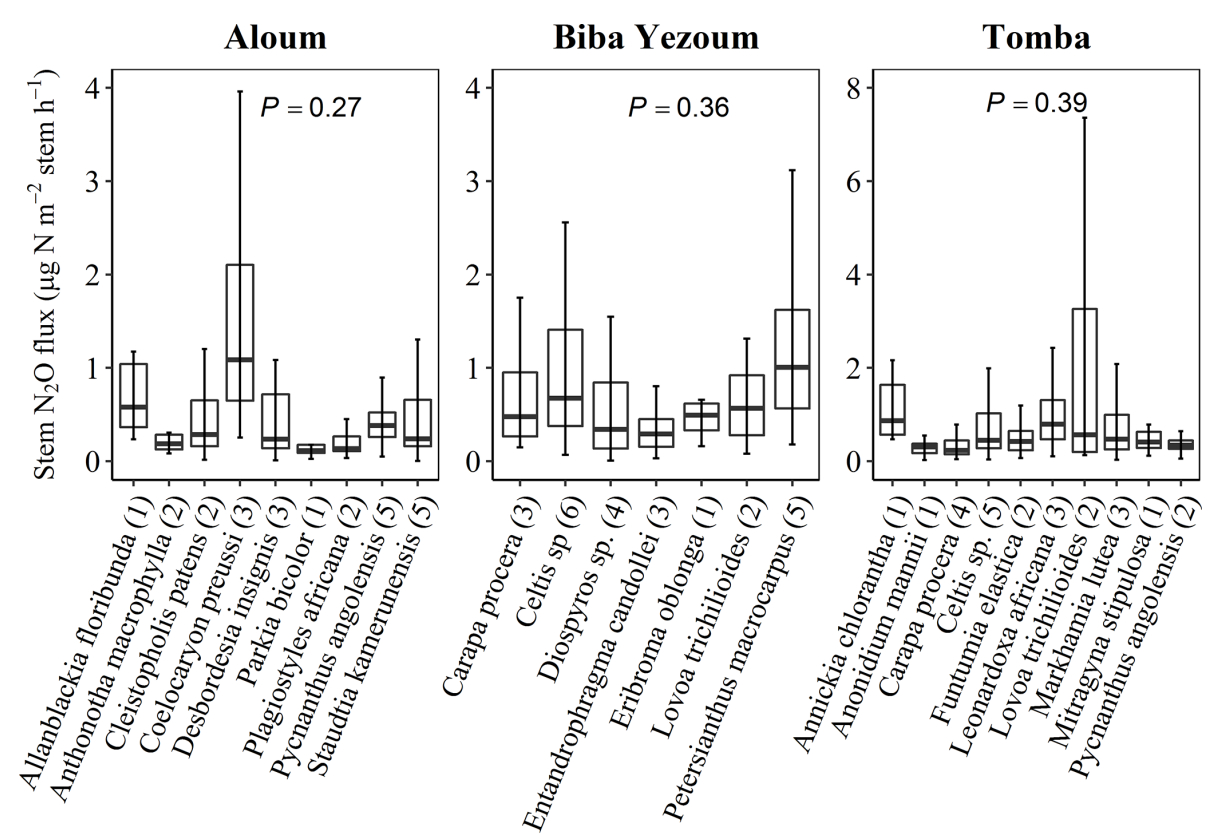

Tree species

Figure 1. Stem $\mathrm{N}_{2} \mathrm{O}$ fluxes from 22 tree species at three forest sites (Aloum, Biba Yezoum and Tomba) across central and south Cameroon in the Congo Basin. Boxes (25th, median and 75th percentile) and whiskers $\left(1.5 \times\right.$ interquartile range) are based on $\mathrm{N}_{2} \mathrm{O}$ fluxes measured monthly from May 2017 to April 2018 for each tree species, and the values in parentheses represent the number of trees measured per species. There were no differences in $\mathrm{N}_{2} \mathrm{O}$ fluxes among species (linear mixed-effect models with Tukey's HSD at $P \geq 0.27$ ).

chambers had airtight seals (Fig. B2). As many of the measured trees have buttresses (rendering stem chambers impossible to attach at low stem height, e.g. Fig. B2), we chose the measurements at an average of $1.3 \mathrm{~m}$ height (or between 1.2 and $1.4 \mathrm{~m}$ ), congruent to the standard measurement of DBH. Since chamber installation is quick, chambers were newly installed on each sampling date, using the silicone sealant strips as a mark to ensure that the same $0.2 \mathrm{~m}$ length stem section was measured. We wrapped a piece of foil (cut approximately $50 \mathrm{~cm}$ longer than the measured stem circumference and fitted with a Luer lock sampling port) around each stem. Using a gas-powered heat gun, we "shrank" the top and bottom parts of the foil to fit closely onto the silicone strips, leaving $0.2 \mathrm{~m}$ length between the top and bottom silicone strips, which served as the chamber for collecting gas samples (Fig. B2). We then wrapped strips of polyethylene foam 
around the edges of the foil and adjusted the foam tightly using lashing straps equipped with ratchet tensioners (two straps at the top and two at the bottom). The lashing straps adjusted the flexible foam and the foil (on top of the silicone strips) to any irregularities on the bark and ensured an airtight fitting. After installation, we completely evacuated the air inside the stem chamber using a syringe fitted with a Luer lock one-way check valve. Afterwards, we used a manual hand pump to refill the stem chamber with a known volume of ambient outside air for correct calculation of stem $\mathrm{N}_{2} \mathrm{O}$ flux. A $25 \mathrm{~mL}$ air sample was taken with a syringe through the Luer lock sampling port immediately after refilling the stem chamber with ambient air and then again after 20, 40 and $60 \mathrm{~min}$. Each air sample was immediately stored in preevacuated $12 \mathrm{~mL}$ Labco Exetainers with rubber septa (Labco Limited, Lampeter, UK), maintaining an overpressure.

In May 2018, we conducted a ${ }^{15} \mathrm{~N}$ tracing experiment at the Tomba site as a follow-on study to elucidate the source of stem $\mathrm{N}_{2} \mathrm{O}$ emissions. The tracing was conducted in three replicate plots per land use, where one tree was selected in each plot. Around each selected tree, $290 \mathrm{mg}{ }^{15} \mathrm{~N}$ (in the form of $\left({ }^{15} \mathrm{NH}_{4}\right)_{2} \mathrm{SO}_{4}$ with $\left.98 \%{ }^{15} \mathrm{~N}\right)$ dissolved in $8 \mathrm{~L}$ distilled water was applied evenly onto the soil surface of $0.8 \mathrm{~m}^{2}$ around the tree using a watering can (equivalent to $10 \mathrm{~mm}$ of rain). The water-filled pore space (WFPS) in the top $5 \mathrm{~cm}$ depth was $49 \pm 1 \%$ and $52 \pm 2 \%$ for the forest and CAF, respectively, which were within the range of monthly average WFPS of these plots (Fig. 2i). Based on the monthly average soil mineral $\mathrm{N}$ concentrations in these plots, the applied ${ }^{15} \mathrm{~N}$ was only $20 \%$ of the extant mineral $\mathrm{N}$ in the top $10 \mathrm{~cm}$ of soil (resulting in a starting enrichment of $17 \%{ }^{15} \mathrm{~N}$ ), such that we only minimally changed the substrate, which could influence $\mathrm{N}_{2} \mathrm{O}$ flux, similar to that described by Corre et al. (2014). Stem and soil ${ }^{15} \mathrm{~N}_{2} \mathrm{O}$ fluxes were measured $1 \mathrm{~d}$, $7 \mathrm{~d}$ and $14 \mathrm{~d}$ following ${ }^{15} \mathrm{~N}$ application, and on each sampling day gas samples were taken at 0,30 and $60 \mathrm{~min}$ after chamber closure. The gas samples were stored in new pre-evacuated glass containers $(100 \mathrm{~mL})$ with rubber septa and transported to the University of Göttingen, Germany, for analysis. We also stored ${ }^{15} \mathrm{~N}_{2} \mathrm{O}$ standards in similar $100 \mathrm{~mL}$ glass containers, which were brought to Cameroon and back to Germany, to have the same storage duration as the gas samples in order to check for leakage; we found no difference in ${ }^{15} \mathrm{~N}_{2} \mathrm{O}$ with the original standard at our laboratory.

We measured soil $\mathrm{N}_{2} \mathrm{O}$ fluxes using vented, static chambers made from polyvinyl chloride that were permanently inserted $\sim 0.02 \mathrm{~m}$ into the soil at least 1 month prior to the start of measurements, as described in our earlier studies (e.g., Corre et al., 2014; Koehler et al., 2009; Müller et al., 2015). On each sampling day, we covered the chamber bases with vented, static polyethylene hoods $\left(0.04 \mathrm{~m}^{2}\right.$ in area and $\sim 11 \mathrm{~L}$ total volume) equipped with Luer lock sampling ports. Soil $\mathrm{N}_{2} \mathrm{O}$ fluxes were then determined by taking four gas samples ( $25 \mathrm{~mL}$ each) at 2, 12, 22 and 32 min after chamber closure. The samples were taken with a syringe and immediately injected into pre-evacuated $12 \mathrm{~mL}$ Exetainers as described above.

Concurrent to the stem and soil $\mathrm{N}_{2} \mathrm{O}$ flux measurements, we sampled soil-air $\mathrm{N}_{2} \mathrm{O}$ concentrations at $50 \mathrm{~cm}$ depth from permanently installed stainless-steel probes $(1 \mathrm{~mm}$ internal diameter) located $\sim 1 \mathrm{~m}$ from the measured trees. The stainless-steel probes were installed 1 month prior to the start of measurements. Luer locks were attached to the probes, and on each sampling day the probes were first cleared of any previous accumulation of $\mathrm{N}_{2} \mathrm{O}$ concentration by removing $5 \mathrm{~mL}$ air volume using a syringe and discarding it. We then took $25 \mathrm{~mL}$ gas samples and stored them in pre-evacuated $12 \mathrm{~mL}$ Exetainers as described above.

\section{$2.3 \quad \mathrm{~N}_{2} \mathrm{O}$ analysis and flux rate calculation}

The $\mathrm{N}_{2} \mathrm{O}$ concentrations in the gas samples were analysed using a gas chromatograph equipped with an electron capture detector, a make-up gas of $5 \% \mathrm{CO}_{2}-95 \% \mathrm{~N}_{2}$ (SRI 8610C, SRI Instruments Europe $\mathrm{GmbH}$, Bad Honnef, Germany) and an autosampler (AS-210, SRI Instruments). ${ }^{15} \mathrm{~N}_{2} \mathrm{O}$ was analysed on an isotope ratio mass spectrometer (IRMS) (Finnigan DELTAplus XP, Thermo Electron Corporation, Bremen, Germany). We calculated $\mathrm{N}_{2} \mathrm{O}$ fluxes from the linear change in concentrations over time of chamber closure, and we adjusted the fluxes with air temperature and atmospheric pressure, measured at each replicate plot on each sampling day. We included zero and negative fluxes in our data analysis.

We up-scaled the measured stem $\mathrm{N}_{2} \mathrm{O}$ fluxes (considering trees $\geq 10 \mathrm{~cm} \mathrm{DBH}$ ) to annual values on a ground area in the following steps: (1) the relationship between stem $\mathrm{N}_{2} \mathrm{O}$ fluxes and stem heights was modelled from the 16 individual trees per land use (see above) that were measured at multiple heights, from which we observed decreases in stem $\mathrm{N}_{2} \mathrm{O}$ fluxes with increasing stem heights. A linear function was statistically the best fit characterizing these decreases in stem $\mathrm{N}_{2} \mathrm{O}$ fluxes with height. (2) Using this linear function and considering the stem surface area as a frustum with $20 \mathrm{~cm}$ increments, the tree-level $\mathrm{N}_{2} \mathrm{O}$ fluxes on each sampling day were calculated for the regularly measured six trees per plot. (3) The annual tree-level $\mathrm{N}_{2} \mathrm{O}$ fluxes from these regularly measured six trees per plot were calculated using a trapezoidal interpolation between the tree-level $\mathrm{N}_{2} \mathrm{O}$ fluxes (step 2) and measurement day intervals from May 2017 to April 2018. (4) The annual tree-level $\mathrm{N}_{2} \mathrm{O}$ fluxes were then extrapolated on a ground-area basis for each replicate plot as follows (Eq. 1):

$$
\begin{aligned}
& \text { annual stem } \mathrm{N}_{2} \mathrm{O} \text { flux }\left(\mathrm{kg} \mathrm{N}_{2} \mathrm{O}-\mathrm{Nha}^{-1} \mathrm{yr}^{-1}\right)= \\
& \frac{\left\{\sum\left[\left(\frac{X_{1-24} / \mathrm{DBH}_{1-24}}{24}\right) \cdot \mathrm{DBH}_{n}\right]\right\}}{A},
\end{aligned}
$$

where $X_{1-24}$ and $\mathrm{DBH}_{1-24}$ are the corresponding annual treelevel $\mathrm{N}_{2} \mathrm{O}$ flux $\left(\mathrm{kg} \mathrm{N}_{2} \mathrm{O}-\mathrm{N} \mathrm{yr}^{-1}\right.$ of each tree; step 3$)$ and DBH $(\mathrm{cm})$ of each of the 24 measured trees $(6$ trees $\times 4$ plots $)$ per 

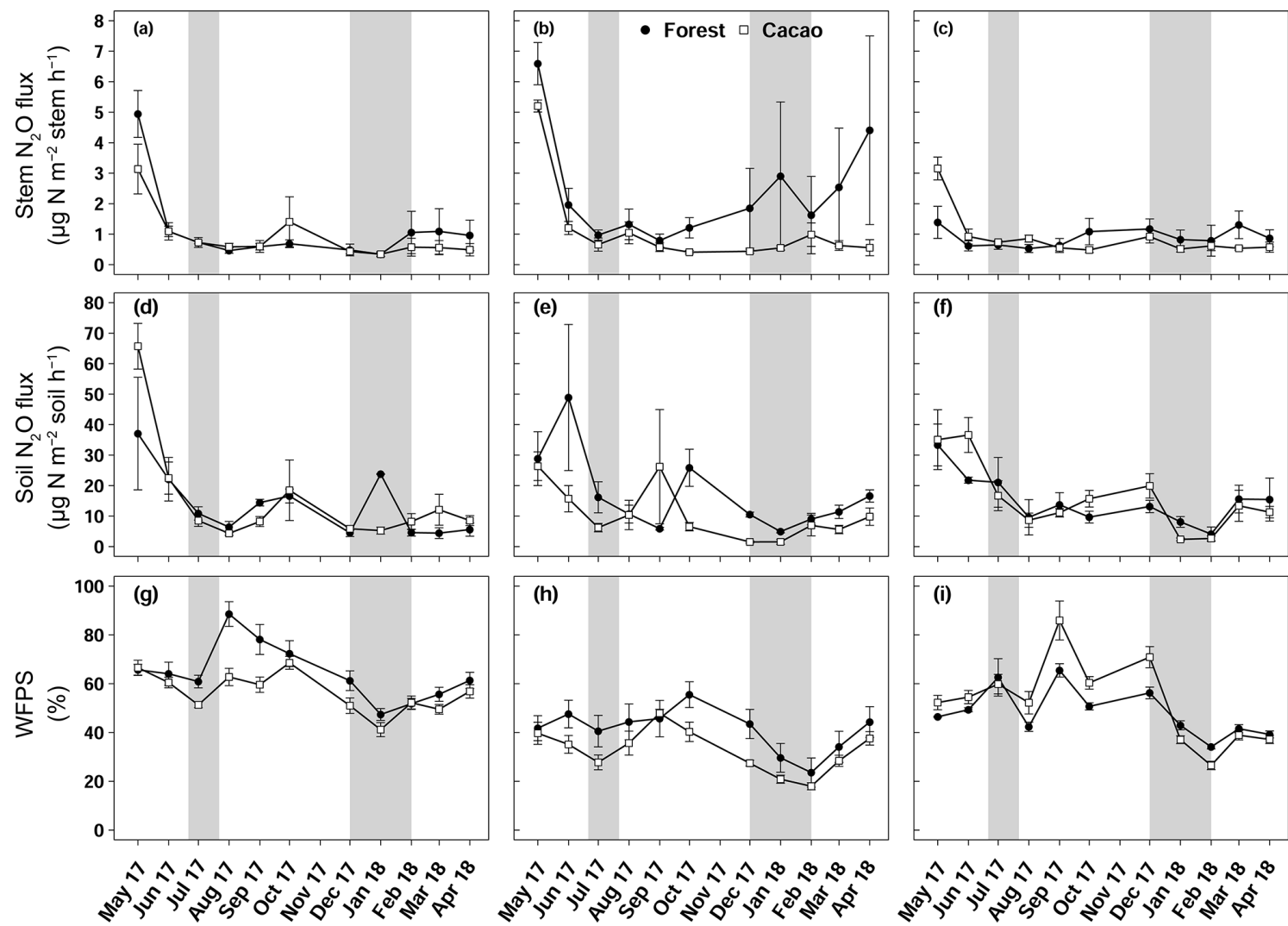

Figure 2. Mean $( \pm \mathrm{SE}, n=4)$ stem $\mathrm{N}_{2} \mathrm{O}$ fluxes $(\mathbf{a}, \mathbf{b}, \mathbf{c})$, soil $\mathrm{N}_{2} \mathrm{O}$ fluxes $(\mathbf{d}, \mathbf{e}, \mathbf{f})$ and water-filled pore space $(\mathbf{g}, \mathbf{h}, \mathbf{i})$ in Aloum site $(\mathbf{a}, \mathbf{d}$, g), Biba Yezoum site (b, e, h) and Tomba site (c, f, i) in the Congo Basin, Cameroon, measured monthly from May 2017 to April 2018 ; grey shadings mark the dry season.

land use at each site, $\mathrm{DBH}_{n}$ is the individual tree $\mathrm{DBH}(\mathrm{cm})$ measured for all trees (with $\geq 10 \mathrm{~cm}$ DBH) present within the inner $40 \mathrm{~m} \times 40 \mathrm{~m}$ area of each plot (Table A1), $\Sigma$ is the sum of the annual $\mathrm{N}_{2} \mathrm{O}$ fluxes of all trees within each plot $\left(\mathrm{kg} \mathrm{N}_{2} \mathrm{O}-\mathrm{N} \mathrm{yr}^{-1}\right)$, and $\mathrm{A}$ is the plot area $(0.16 \mathrm{ha})$.

For step 4 of the CAF plots, the annual stem $\mathrm{N}_{2} \mathrm{O}$ flux was the sum of the cacao and shade trees (Table A1); as these shade trees were remnants of the original forest, we used the average annual tree-level $\mathrm{N}_{2} \mathrm{O}$ flux of the measured trees in the corresponding paired forest plots multiplied by the actual DBH of the shade trees in the CAF plots. This spatial extrapolation based on trees' DBH of each plot was also supported by the fact that there were no significant differences in stem $\mathrm{N}_{2} \mathrm{O}$ fluxes among tree species (Fig. 1).

Annual soil $\mathrm{N}_{2} \mathrm{O}$ fluxes from each plot were calculated using the trapezoidal rule to interpolate the measured fluxes from May 2017 to April 2018, as employed in our earlier studies (e.g., Koehler et al., 2009; Veldkamp et al., 2013). Finally, the annual $\mathrm{N}_{2} \mathrm{O}$ fluxes from each replicate plot were represented by the sum of the stem and soil $\mathrm{N}_{2} \mathrm{O}$ fluxes.

\subsection{Soil and meteorological variables}

We measured soil temperature, WFPS and extractable mineral $\mathrm{N}$ in the top $5 \mathrm{~cm}$ of depth concurrent to stem and soil $\mathrm{N}_{2} \mathrm{O}$ flux measurements on each sampling day. The soil temperature was measured $\sim 1 \mathrm{~m}$ away from the soil chambers using a digital thermometer (GTH 175, Greisinger Electronic $\mathrm{GmbH}$, Regenstauf, Germany). We determined soil WFPS and extractable mineral $\mathrm{N}$ by pooling soil samples from four sampling locations within $1 \mathrm{~m}$ from each soil chamber in each replicate plot. Gravimetric moisture content was determined by oven-drying the soils at $105^{\circ} \mathrm{C}$ for $24 \mathrm{~h}$, and WFPS was calculated using a particle density of $2.65 \mathrm{~g} \mathrm{~cm}^{-3}$ for mineral soil and our measured soil bulk density (Table 1). Soil mineral $\mathrm{N}\left(\mathrm{NO}_{3}^{-}\right.$and $\left.\mathrm{NH}_{4}^{+}\right)$was extracted in the field by putting a subsample of soil into a pre-weighed bottle containing $150 \mathrm{~mL}$ of $0.5 \mathrm{M} \mathrm{K}_{2} \mathrm{SO}_{4}$. The bottles were weighed and then shaken for $1 \mathrm{~h}$, and the solution was filtered through pre-washed (with $0.5 \mathrm{M} \mathrm{K}_{2} \mathrm{SO}_{4}$ ) filter papers. The extracts were immediately frozen and later transported to the University of Göttingen, where $\mathrm{NH}_{4}^{+}$and $\mathrm{NO}_{3}^{-}$concentrations were analysed using continuous-flow injection calorimetry (SEAL Analytical AA3, SEAL Analytical GmbH, Norderstedt, Germany) (described in detail by Hassler et al., 2015). The dry 
mass of soil extracted for mineral $\mathrm{N}$ was calculated using the measured gravimetric moisture content.

During each measurement day, we set up a portable weather station at each site to record relative humidity and air temperature over the course of each sampling day at $15 \mathrm{~min}$ intervals. We calculated vapour pressure deficit (VPD) as the difference between saturation vapour pressure (based on its established equation with air temperature) and actual vapour pressure (using saturation vapour pressure and relative humidity; Allen et al., 1998).

Soil biochemical characteristics were measured in April 2017 at all 24 plots. We collected soil samples from the top $50 \mathrm{~cm}$ depth, where changes in soil biochemical characteristics resulting from land-use changes have been shown to occur (van Straaten et al., 2015; Tchiofo Lontsi et al., 2019). In each plot, we collected 10 soil samples from the top $0-10 \mathrm{~cm}$ and five soil samples each from 10-30 and 30$50 \mathrm{~cm}$ depths; in total, we collected 480 soil samples from the 24 plots. The soil samples were air-dried, sieved $(2 \mathrm{~mm})$ and transported to the University of Göttingen, where they were dried again at $40^{\circ} \mathrm{C}$ before analysis. Soil $\mathrm{pH}$ was analysed from a $1: 4$ soil-to-distilled water ratio. Soil texture for each plot was determined using the pipette method after iron oxide and organic matter removal (Kroetsch and Wang, 2008). Effective cation exchange capacity (ECEC) and exchangeable cation concentrations $(\mathrm{Ca}, \mathrm{Mg}, \mathrm{K}, \mathrm{Na}, \mathrm{Al}, \mathrm{Fe}$, $\mathrm{Mn})$ were determined by percolating the soil samples with unbuffered $1 \mathrm{M} \mathrm{NH}_{4} \mathrm{Cl}$, and the extracts were analysed using an inductively coupled plasma atomic emission spectrometer (ICP-AES; iCAP 6300 Duo VIEW ICP spectrometer, Thermo Fisher Scientific GmbH, Dreieich, Germany). Soil subsamples were ground and analysed for total organic $\mathrm{C}$ and $\mathrm{N}$ using a $\mathrm{CN}$ analyser (vario EL cube; Elementar Analysis Systems $\mathrm{GmbH}$, Hanau, Germany), and the soil ${ }^{15} \mathrm{~N}$ natural abundance signatures were determined using IRMS (DELTAplus; Finnigan MAT, Bremen, Germany). Soil organic carbon (SOC) and total $\mathrm{N}$ stocks were calculated for the top $50 \mathrm{~cm}$ in both land uses. We used the bulk density of the reference forest for calculating the SOC and total $\mathrm{N}$ stocks of the converted CAF in order to avoid overestimations of element stocks resulting from increases in soil bulk densities following land-use conversion (van Straaten et al., 2015; Veldkamp, 1994).

To evaluate the representativeness of our study area with the rest of the Congo Basin rainforest, we estimated the proportion of the Congo rainforest area that has similar biophysical conditions (elevation, precipitation ranges and soil type) as our study sites (Table A1). Using the FAO's Global Ecological Zone map for the humid tropics, we identified the areal coverage of (i) Ferralsols (FAO Harmonized World Soil Database; FAO/IIASA/ISRIC/ISSCAS/JRC, 2012) with (ii) elevation $\leq 1000 \mathrm{~m}$ a.s.l. (SRTM digital elevation model; Jarvis et al., 2008) and (iii) a precipitation range between 1500 and $2100 \mathrm{~mm} \mathrm{yr}^{-1}$ (WorldClim dataset; Hijmans et al., 2005) within the six Congo rainforest countries (Fig. B3). This analysis was conducted using QGIS version 3.6.3.

\subsection{Statistical analyses}

Statistical comparisons between land uses or among sites for stem and soil $\mathrm{N}_{2} \mathrm{O}$ fluxes were performed on the monthly measurements and not on the annual values as the latter are trapezoidal interpolations. As the six trees and four chambers per plot were considered subsamples representing each replicate plot, we conducted the statistical analysis using the means of the six trees and of the four chambers on each sampling day for each replicate plot (congruent to our previous studies, e.g., Hassler et al., 2017; Matson et al., 2017). We tested each parameter for normal distribution (ShapiroWilk's test) and homogeneity of variance (Levene's test), and we applied a logarithmic or square root transformation when these assumptions were not met. For the repeatedly measured parameters, i.e. stem and soil $\mathrm{N}_{2} \mathrm{O}$ fluxes and the accompanying soil variables (temperature, WFPS, $\mathrm{NH}_{4}^{+}$and $\mathrm{NO}_{3}^{-}$concentrations), differences between land-use types for each site or differences among sites for each land-use type were tested using linear mixed-effect (LME) models with land use or site as the fixed effect and replicate plots and sampling days as random effects (Crawley, 2009). We assessed significant differences between land uses or sites using analysis of variance (ANOVA) with Tukey's HSD test.

We also analysed whether there were differences in stem $\mathrm{N}_{2} \mathrm{O}$ fluxes among tree species across four forest plots at each site as well as across the three sites. Similar LME analysis was carried out with tree species as the fixed effect, and the random effects were trees belonging to each species and sampling days; only, for this test, we used individual trees as the random effect because most of the tree species (selected based on their IVI; see Sect. 2.1) were not present in all plots, which is typical in species-diverse tropical forest. For soil biochemical characteristics that were measured once (Table 1), one-way ANOVA followed by a Tukey HSD test was used to assess the differences between land uses or sites for the variables with normal distribution and homogenous variance; otherwise, we applied Kruskal-Wallis ANOVA with a multiple-comparison extension test.

To determine the temporal controls of soil and meteorological variables (temperature, WFPS, $\mathrm{NH}_{4}^{+}$and $\mathrm{NO}_{3}^{-}$concentrations, soil-air $\mathrm{N}_{2} \mathrm{O}$ concentration, VPD) on stem and soil $\mathrm{N}_{2} \mathrm{O}$ fluxes, we conducted Spearman's rank correlation tests using the means of the four replicate plots for each land use on each sampling day. For each land use, the correlation tests were conducted across sites and sampling days ( $n=33$, from 3 sites $\times 11$ monthly measurements). To determine the spatial controls of soil biochemical characteristics (which were measured once, Table 1) on stem and soil $\mathrm{N}_{2} \mathrm{O}$ fluxes, we used the plots' annual $\mathrm{N}_{2} \mathrm{O}$ emissions and tested with Spearman's rank correlation across land uses and sites ( $n=24$, from three sites times two land uses times four repli- 
cate plots). The statistical significance for all the tests was set at $P \leq 0.05$. All statistical analyses were conducted using the open-source software R 3.5.2 (R Core Team, 2018).

\section{Results}

\subsection{Stem $\mathrm{N}_{2} \mathrm{O}$ emissions}

Stem $\mathrm{N}_{2} \mathrm{O}$ emissions differed neither between forest and CAF at each site $(P=0.15-0.76$; Table 2$)$ nor among the three sites for each land use $(P=0.16-0.78$; Table 2). There were also no differences in stem $\mathrm{N}_{2} \mathrm{O}$ emissions among tree species in forest plots at each site as well as across the three sites ( $P=0.06-0.39$; Fig. 1$)$. For the forests, stem $\mathrm{N}_{2} \mathrm{O}$ emissions exhibited a seasonal pattern with larger fluxes in the wet season than in the dry season at all sites (all $P<0.01$; Table A3; Fig. 2a, b, c). However, for the CAF, we observed seasonal differences only at the Aloum site $(P<0.01$; Table A4; Fig. 2a). Contributions of annual stem $\mathrm{N}_{2} \mathrm{O}$ emissions reached up to one-third of the total (stem + soil) $\mathrm{N}_{2} \mathrm{O}$ emissions from the forests (Table 2).

From the ${ }^{15} \mathrm{~N}$-tracing experiment, stem ${ }^{15} \mathrm{~N}-\mathrm{N}_{2} \mathrm{O}$ emissions mirrored soil ${ }^{15} \mathrm{~N}-\mathrm{N}_{2} \mathrm{O}$ emissions from both land uses (Fig. 3). About $1 \mathrm{~d}$ after ${ }^{15} \mathrm{~N}$ addition to the soil, substantial ${ }^{15} \mathrm{~N}-\mathrm{N}_{2} \mathrm{O}$ was emitted from the stem as well as from the soil. This diminished within 2 weeks as the added ${ }^{15} \mathrm{~N}$ recycled within the soil $\mathrm{N}$ cycling processes, diluting the ${ }^{15} \mathrm{~N}$ signatures; nevertheless, the ${ }^{15} \mathrm{~N}$ signatures of stem- and soilemitted $\mathrm{N}_{2} \mathrm{O}$ remained elevated above the natural abundance level (Fig. 3).

Across the study period, stem $\mathrm{N}_{2} \mathrm{O}$ emissions from the forests were positively correlated with air temperature, soilair $\mathrm{N}_{2} \mathrm{O}$ concentrations and VPD (Table 3) and negatively correlated with WFPS and $\mathrm{NH}_{4}^{+}$contents (Table 3). The negative correlation of stem $\mathrm{N}_{2} \mathrm{O}$ emissions with WFPS was possibly spurious, as this correlation may have been driven by the autocorrelation between WFPS and air temperature (Spearman's $\rho=-0.59, P<0.01, n=33$ ). In CAF, stem $\mathrm{N}_{2} \mathrm{O}$ emissions were only positively correlated with soil $\mathrm{N}_{2} \mathrm{O}$ emissions (Table 3).

We detected no difference in WFPS between the forest and CAF ( $P=0.15-0.28$; Table 4$)$ at any of the sites. For the CAF, we detected higher WFPS in the wet season compared to the dry season at two sites $(P<0.01$; Table A4; Fig. $2 \mathrm{~g}$, h) whereas there was no seasonal difference in WFPS for the forests at any sites ( $P=0.31-0.92$; Table A3; Fig. $2 \mathrm{~g}, \mathrm{~h}, \mathrm{i})$. At all three sites, the dominant form of mineral $\mathrm{N}$ was $\mathrm{NH}_{4}^{+}$ (Table 4). There was generally no difference in soil $\mathrm{NH}_{4}^{+}$and $\mathrm{NO}_{3}^{-}$between the wet and dry seasons $(P=0.12-0.93)$, except for the forests at two sites with larger values in the dry than wet season $(P<0.01$; Tables S2, S3).
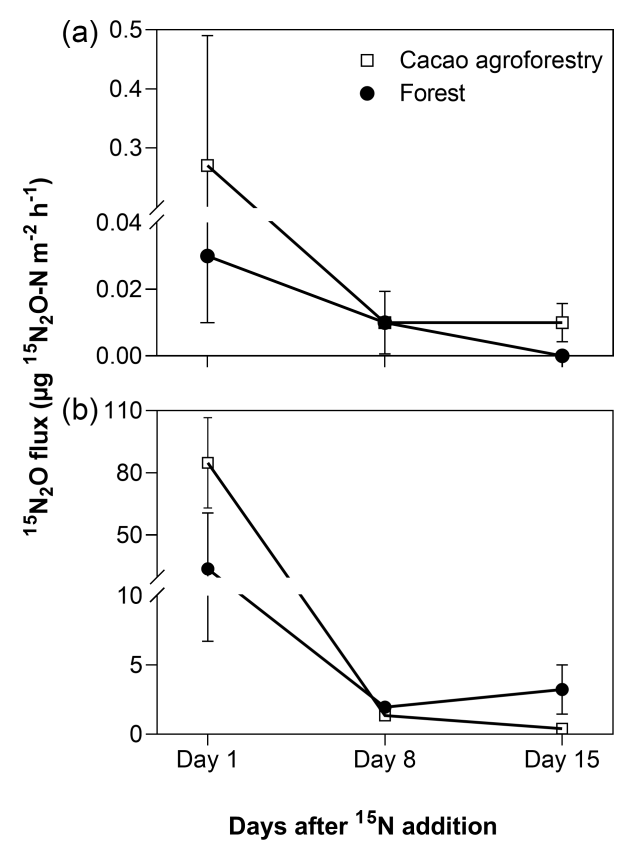

Figure 3. Mean ( $\pm \mathrm{SE}, n=3){ }^{15} \mathrm{~N}_{2} \mathrm{O}$ fluxes from stems (a, unit is per square metre of stem area) and soil (b, unit is per square metre of ground area) in the Congo Basin, Cameroon. In May 2018, $290 \mathrm{mg}{ }^{15} \mathrm{~N}$ (in the form of $\left({ }^{15} \mathrm{NH}_{4}\right)_{2} \mathrm{SO}_{4}$ with $98 \%{ }^{15} \mathrm{~N}$ ) was dissolved in $8 \mathrm{~L}$ distilled water and sprayed within a $0.8 \mathrm{~m}^{2}$ area around each tree (equal to $10 \mathrm{~mm}$ rain), which was only $20 \%$ of the extant mineral $\mathrm{N}$ in the top $10 \mathrm{~cm}$ of soil and $49 \pm 1 \%$ and $52 \pm 2 \%$ waterfilled pore space for the forest and CAF, respectively, comparable to the soil water content of the site (Fig. 2).

\subsection{Soil $\mathrm{N}_{2} \mathrm{O}$ emissions}

Soil $\mathrm{N}_{2} \mathrm{O}$ emissions did not differ between forest and $\mathrm{CAF}$ at any site $(P=0.06-0.86$; Table 2$)$. Similarly, no differences in soil $\mathrm{N}_{2} \mathrm{O}$ emissions were detected among sites for each land use ( $P=0.26-0.44$; Table 2$)$. Soil $\mathrm{N}_{2} \mathrm{O}$ emissions exhibited consistent seasonal patterns with larger fluxes in the wet than dry season for both land uses (all $P<0.01$; Tables S2, S3; Fig. 2d, e, f).

Over the measurement period, soil $\mathrm{N}_{2} \mathrm{O}$ emissions from the forests were positively correlated with soil-air $\mathrm{N}_{2} \mathrm{O}$ concentrations and negatively correlated with $\mathrm{NH}_{4}^{+}$contents (Table 3 ). In the $\mathrm{CAF}$, soil $\mathrm{N}_{2} \mathrm{O}$ emissions were positively correlated with WFPS and soil-air $\mathrm{N}_{2} \mathrm{O}$ concentrations and negatively correlated with air temperatures (Table 3 ). We did not detect any correlation between annual total $\mathrm{N}_{2} \mathrm{O}$ fluxes and soil physical and biochemical characteristics. This was not surprising as the ranges of these soil characteristics were relatively small among sites, which reduces the likelihood that significant correlations will be detected. 
Table 2. Mean ( $\pm \mathrm{SE}, n=4)$ stem and soil $\mathrm{N}_{2} \mathrm{O}$ emission as well as annual stem, soil and total (soil + stem) $\mathrm{N}_{2} \mathrm{O}$ fluxes from forest and cacao agroforestry (CAF) within each site in the Congo Basin, Cameroon. Means followed by different lowercase letters indicate significant differences between land-use types within each site, and different capital letters indicate significant differences among the three sites within a land-use type (linear mixed-effect models with Tukey's HSD at $P \leq 0.05$ ).

\begin{tabular}{|c|c|c|c|c|c|c|}
\hline $\begin{array}{l}\text { Site/land- } \\
\text { use type }\end{array}$ & $\begin{array}{r}\text { Stem } \mathrm{N}_{2} \mathrm{O} \\
\text { fluxes }(\mu \mathrm{g} \mathrm{N} \\
\left.\mathrm{m}^{-2} \text { stem }^{-1}\right)\end{array}$ & $\begin{array}{r}\text { Annual stem } \\
\mathrm{N}_{2} \mathrm{O} \text { fluxes* } \\
\left(\mathrm{kg} \mathrm{Nha}^{-1} \mathrm{yr}^{-1}\right)\end{array}$ & $\begin{array}{r}\text { Soil } \mathrm{N}_{2} \mathrm{O} \\
\text { fluxes }(\mu \mathrm{g} \mathrm{N} \\
\left.\mathrm{m}^{-2} \operatorname{soil~h}^{-1}\right)\end{array}$ & $\begin{array}{r}\text { Annual soil } \\
\mathrm{N}_{2} \mathrm{O} \text { fluxes* } \\
\left(\mathrm{kg} \mathrm{Nha}^{-1} \mathrm{yr}^{-1}\right)\end{array}$ & $\begin{array}{r}\text { Total (soil }+ \\
\text { stem) } \mathrm{N}_{2} \mathrm{O} \text { flux } \\
\left(\mathrm{kg} \mathrm{Nha}^{-1} \mathrm{yr}^{-1}\right)\end{array}$ & $\begin{array}{r}\text { Contribution } \\
\text { of stem to total } \\
\mathrm{N}_{2} \mathrm{O} \text { flux }(\%)\end{array}$ \\
\hline \multicolumn{7}{|l|}{ Aloum } \\
\hline Forest & $1.13 \pm 0.22^{\mathrm{a}, \mathrm{A}}$ & $0.13 \pm 0.00$ & $13.7 \pm 2.2^{\mathrm{a}, \mathrm{A}}$ & $0.87 \pm 0.14$ & $1.00 \pm 0.14$ & $13.7 \pm 1.8$ \\
\hline CAF & $0.90 \pm 0.16^{\mathrm{a}, \mathrm{A}}$ & $\begin{array}{r}0.09 \pm 0.01 \\
(0.02 \pm 0.01)\end{array}$ & $15.2 \pm 2.8^{\mathrm{a}, \mathrm{A}}$ & $1.06 \pm 0.17$ & $1.15 \pm 0.17$ & $7.8 \pm 1.6$ \\
\hline \multicolumn{7}{|c|}{ Biba Yezoum } \\
\hline Forest & $2.38 \pm 0.48^{\mathrm{a}, \mathrm{A}}$ & $0.87 \pm 0.05$ & $17.2 \pm 2.9^{\mathrm{a}, \mathrm{A}}$ & $1.46 \pm 0.23$ & $2.33 \pm 0.24$ & $38.2 \pm 3.5$ \\
\hline CAF & $1.11 \pm 0.21^{\mathrm{a}, \mathrm{A}}$ & $\begin{array}{r}0.12 \pm 0.01 \\
(0.03 \pm 0.01)\end{array}$ & $10.6 \pm 2.1^{\mathrm{a}, \mathrm{A}}$ & $0.80 \pm 0.20$ & $0.92 \pm 0.20$ & $14.8 \pm 3.0$ \\
\hline \multicolumn{7}{|l|}{ Tomba } \\
\hline Forest & $0.89 \pm 0.10^{\mathrm{a}, \mathrm{A}}$ & $0.14 \pm 0.01$ & $15.0 \pm 1.7^{\mathrm{a}, \mathrm{A}}$ & $1.18 \pm 0.18$ & $1.31 \pm 0.18$ & $11.4 \pm 2.2$ \\
\hline CAF & $0.90 \pm 0.12^{\mathrm{a}, \mathrm{A}}$ & $\begin{array}{r}0.12 \pm 0.00 \\
(0.05 \pm 0.02)\end{array}$ & $15.8 \pm 2.0^{\mathrm{a}, \mathrm{A}}$ & $1.25 \pm 0.14$ & $1.37 \pm 0.14$ & $8.9 \pm 0.9$ \\
\hline
\end{tabular}

$*$ Annual stem and soil $\mathrm{N}_{2} \mathrm{O}$ fluxes were not statistically tested for differences among sites or between land-use types since these annual values are trapezoidal
extrapolations. Annual stem $\mathrm{N}_{2} \mathrm{O}$ emissions in parentheses are from cacao trees only.

Table 3. Spearman correlation coefficients of stem $\mathrm{N}_{2} \mathrm{O}$ flux $\left(\mu \mathrm{g} \mathrm{N} \mathrm{m}^{-2}\right.$ stem h$\left.^{-1}\right)$ and soil $\mathrm{N}_{2} \mathrm{O}$ flux $\left(\mu g \mathrm{~N} \mathrm{~m}^{-2}\right.$ soil h$\left.^{-1}\right)$ with air temperature $\left({ }^{\circ} \mathrm{C}\right)$, water-filled pore space (WFPS) $\left(\%\right.$, top $5 \mathrm{~cm}$ depth), extractable $\mathrm{NH}_{4}^{+}\left(\mathrm{mg} \mathrm{N} \mathrm{kg}^{-1}\right.$, top $5 \mathrm{~cm}$ depth), soil-air $\mathrm{N}_{2} \mathrm{O}$ concentration (ppm $\mathrm{N}_{2} \mathrm{O}$ at $50 \mathrm{~cm}$ depth) and vapour pressure deficit (VPD) (kPa), using the monthly means of the four replicate plots per land use across the three sites from May 2017 to April $2018(n=33)$.

\begin{tabular}{llrrrrrr}
\hline Land use & Variable & $\begin{array}{r}\text { Soil } \mathrm{N}_{2} \mathrm{O} \\
\text { flux }\end{array}$ & Air temp. & WFPS & $\mathrm{NH}_{4}^{+}$ & $\begin{array}{r}\text { Soil-air } \mathrm{N}_{2} \mathrm{O} \\
\text { concentration }\end{array}$ & VPD \\
\hline \multirow{2}{*}{ Forest } & Stem $\mathrm{N}_{2} \mathrm{O}$ flux & 0.25 & $0.39^{\mathrm{a}}$ & $-0.41^{\mathrm{a}}$ & $-0.57^{\mathrm{b}}$ & $0.41^{\mathrm{a}}$ & $0.62^{\mathrm{b}}$ \\
& Soil $\mathrm{N}_{2} \mathrm{O}$ flux & & -0.07 & 0.15 & $-0.43^{\mathrm{a}}$ & $0.55^{\mathrm{b}}$ & -0.01 \\
\hline \multirow{2}{*}{$\mathrm{CAF}$} & Stem $\mathrm{N}_{2} \mathrm{O}$ flux & $0.60^{\mathrm{a}}$ & -0.29 & 0.17 & -0.26 & 0.21 & 0.21 \\
& Soil N & & & & \\
& & & $-0.34^{\mathrm{a}}$ & $0.53^{\mathrm{b}}$ & -0.14 & $0.51^{\mathrm{b}}$ & 0.10 \\
\hline
\end{tabular}

${ }^{\mathrm{a}} P \leq 0.05{ }^{\mathrm{b}} P \leq 0.01$.

\subsection{Soil biochemical characteristics}

Soil physical characteristics (clay content, bulk density) did not differ between forest and CAF at any of the sites (Table 1). Across sites, Biba Yezoum had lower clay content compared to the other sites for each land use $(P<0.01)$. Generally, the forest showed higher SOC and total N compared to the CAF $(P<0.01-0.05$; Table 1$)$. Soil ${ }^{15} \mathrm{~N}$ natural abundance signatures, as an index of the long-term soil $\mathrm{N}$ availability, were generally similar between the forest and CAF except at the Aloum site $(P<0.01$; Table 1$)$. Soil C / N ratio, another proxy for the long-term soil $\mathrm{N}$ status, was higher in the forest than in the CAF at all sites $(P<0.01-$ $0.05)$. Soil $\mathrm{pH}$ and exchangeable bases were lower in the for- est compared to the $\mathrm{CAF}$ at all sites and the converse was true for exchangeable $\mathrm{Al}(P<0.01-0.05$; Table 1). Soil ECEC did not differ between the land uses at two sites $(P<0.01$; Table 1) and all were low congruent to Ferralsol soils.

\section{Discussion}

\subsection{Stem and soil $\mathrm{N}_{2} \mathrm{O}$ emissions from the forest}

There has been no study on tree stem $\mathrm{N}_{2} \mathrm{O}$ emission from Africa, nor has any study been reported for the Congo Basin on soil $\mathrm{N}_{2} \mathrm{O}$ emission with year-round measurements and spatial replication. Stems consistently emitted $\mathrm{N}_{2} \mathrm{O}$ in both land uses (Table 2; Figs. 1, 2a, b, c), exemplifying that trop- 
Table 4. Mean ( \pm SE, $n=4)$ water-filled pore space (WFPS) and extractable mineral $\mathrm{N}$ in the top $5 \mathrm{~cm}$ of soil in forest and cacao agroforestry (CAF) within each site in Congo Basin, Cameroon, measured monthly from May 2017 to April 2018.

\begin{tabular}{lrrr}
\hline $\begin{array}{l}\text { Site/land- } \\
\text { use type* }\end{array}$ & $\begin{array}{r}\text { WFPS } \\
(\%)\end{array}$ & $\begin{array}{r}\mathrm{NH}_{4}^{+} \\
\left(\mathrm{mg} \mathrm{N} \mathrm{kg}^{-1}\right)\end{array}$ & $\begin{array}{r}\mathrm{NO}_{3}^{-} \\
\left(\mathrm{mg} \mathrm{N} \mathrm{kg}^{-1}\right)\end{array}$ \\
\hline Aloum & & & \\
\hline Forest & $64.3 \pm 3.6^{\mathrm{a}, \mathrm{A}}$ & $7.3 \pm 1.0^{\mathrm{a}, \mathrm{A}}$ & $6.3 \pm 1.2^{\mathrm{a}, \mathrm{A}}$ \\
CAF & $56.4 \pm 2.5^{\mathrm{a}, \mathrm{A}}$ & $5.1 \pm 0.8^{\mathrm{a}, \mathrm{B}}$ & $2.4 \pm 0.6^{\mathrm{b}, \mathrm{A}}$ \\
\hline Biba Yezoum & & \\
\hline Forest & $41.5 \pm 2.7^{\mathrm{a}, \mathrm{B}}$ & $4.9 \pm 0.4^{\mathrm{b}, \mathrm{B}}$ & $2.9 \pm 0.5^{\mathrm{a}, \mathrm{B}}$ \\
CAF & $32.6 \pm 2.7^{\mathrm{a}, \mathrm{B}}$ & $7.3 \pm 0.4^{\mathrm{a}, \mathrm{A}}$ & $2.7 \pm 0.6^{\mathrm{a}, \mathrm{A}}$ \\
\hline Tomba & & & \\
\hline Forest & $48.3 \pm 3.0^{\mathrm{a}, \mathrm{B}}$ & $7.6 \pm 0.6^{\mathrm{a}, \mathrm{A}}$ & $5.8 \pm 1.0^{\mathrm{a}, \mathrm{A}}$ \\
CAF & $52.3 \pm 5.1^{\mathrm{a}, \mathrm{A}}$ & $7.1 \pm 0.6^{\mathrm{a}, \mathrm{A}}$ & $2.8 \pm 0.6^{\mathrm{b}, \mathrm{A}}$ \\
\hline
\end{tabular}

* Means followed by different lowercase letters indicate significant differences between land-use types within each site and different capital letters indicate significant differences among the three sites within a land-use type (linear mixed-effect models with Tukey's HSD at $P \leq 0.05$ ).

ical trees on well-drained soils were important contributors of ecosystem $\mathrm{N}_{2} \mathrm{O}$ emission. So far, there are only two tree species of tropical lowland forest reported with measurements of stem $\mathrm{N}_{2} \mathrm{O}$ emissions (Welch et al., 2019). Our present study included 23 tree species and their comparable stem $\mathrm{N}_{2} \mathrm{O}$ emissions, at least from highly weathered Ferralsol soils, across sites over a year of measurements, which provided support to our spatial extrapolation based on DBH of trees at the sites. Mean stem $\mathrm{N}_{2} \mathrm{O}$ fluxes from our study were within the range of those reported for temperate forests $\left(0.01-2.2 \mu \mathrm{g} \mathrm{N} \mathrm{m}^{-2}\right.$ stem h$^{-1}$; Díaz-Pinés et al., 2016; Machacova et al., 2016; Wen et al., 2017) but substantially lower than the reported stem $\mathrm{N}_{2} \mathrm{O}$ emissions of 51$759 \mu \mathrm{g} \mathrm{N} \mathrm{m}^{-2} \mathrm{stem} \mathrm{h}^{-1}$ for a humid forest in Panama (Welch et al., 2019). However, Welch et al. (2019) measured stem $\mathrm{N}_{2} \mathrm{O}$ emissions at a lower stem height $(0.3 \mathrm{~m})$ compared to our study $(1.3 \mathrm{~m})$, which may partly explain their much larger $\mathrm{N}_{2} \mathrm{O}$ emissions, as other studies reported that larger $\mathrm{N}_{2} \mathrm{O}$ emissions occur closer to the stem base of trees (Barba et al., 2019; Díaz-Pinés et al., 2016). Moreover, the consistently higher stem than soil $\mathrm{N}_{2} \mathrm{O}$ emissions found by Welch et al. (2019), which we did not observe in our study, may point to production of $\mathrm{N}_{2} \mathrm{O}$ within the stem (e.g., Lenhart et al., 2019). Nonetheless, such high stem $\mathrm{N}_{2} \mathrm{O}$ emissions as reported by Welch et al. (2019) have not been observed anywhere else under field conditions. We did not find an effect of tree diameter sizes on stem $\mathrm{N}_{2} \mathrm{O}$ fluxes at our study sites. This was due to the narrow range between the DBH of our measured trees (10-18 cm DBH for cacao trees and 10$30 \mathrm{~cm}$ DBH for the forest trees), which reflected the mean stem diameter of trees in our sites (Table A1). Future stud- ies should incorporate trees of wide-ranging diameter size classes, if present at the site, as they may influence $\mathrm{N}_{2} \mathrm{O}$ flux estimates at the ecosystem scale.

Our annual soil $\mathrm{N}_{2} \mathrm{O}$ emissions from forests (Table 2) were lower than the reported global average for humid tropical forests $\left(2.81 \mathrm{~kg} \mathrm{~N} \mathrm{ha}^{-1} \mathrm{yr}^{-1}\right.$; summarized by Castaldi et al., 2013). In contrast, the $\mathrm{N}_{2} \mathrm{O}$ emissions from our forest soils were comparable to those reported for lowland forests on Ferralsol soils in Panama (0.35-1.07 kg N ha ${ }^{-1} \mathrm{yr}^{-1}$; Matson et al., 2017) and lowland forests on Acrisol soils in Indonesia (0.9 and $1.0 \mathrm{~kg} \mathrm{~N} \mathrm{ha}^{-1} \mathrm{yr}^{-1}$; Hassler et al., 2017). These were possibly due to the soil $\mathrm{N}$ availability at our forest sites generally similar to that of forest sites in Panama and Indonesia, indicated by their comparable soil mineral $\mathrm{N}$ contents and soil ${ }^{15} \mathrm{~N}$ natural abundance signatures.

In comparison with studies from sub-Saharan Africa, annual soil $\mathrm{N}_{2} \mathrm{O}$ emissions from our forests were lower than the annual $\mathrm{N}_{2} \mathrm{O}$ emissions reported for the Mayombe forest in the Congo $\left(2.9 \mathrm{~kg} \mathrm{Nha}^{-1} \mathrm{yr}^{-1}\right.$; Serca et al., 1994), Kakamega mountain rainforest in Kenya (2.6 $\mathrm{kg} \mathrm{N} \mathrm{ha}^{-1} \mathrm{yr}^{-1}$; Werner et al., 2007b) and Ankasa rainforest in Ghana (2.3 $\mathrm{kg} \mathrm{N} \mathrm{ha}^{-1} \mathrm{yr}^{-1}$; Castaldi et al., 2013) but similar in magnitude to those reported for Mau Afromontane forest in Kenya $\left(1.1 \mathrm{~kg} \mathrm{Nha}^{-1} \mathrm{yr}^{-1}\right.$; Wanyama et al., 2018). Although these African sites have precipitation levels and highly weathered acidic soils similar to those of our study sites, the Kakamega rainforest in Kenya had higher SOC $(7.9 \%-20 \%)$ and $\mathrm{N}$ contents $(0.5 \%-1.6 \%)$ in the topsoil layer compared to our forest sites $(2.8 \%-4.7 \%$ SOC, $0.2 \%-0.4 \%$ total $\mathrm{N}$ ), which may explain its correspondingly higher soil $\mathrm{N}_{2} \mathrm{O}$ emissions. The study in Congo (Serca et al., 1994), however, was conducted only in a short campaign (2 rainy months and 1 dry month) with less sampling frequency and spatial replication, which may not be a good representation of the spatial and temporal dynamics of soil $\mathrm{N}_{2} \mathrm{O}$ fluxes to achieve an annual and large-scale estimate.

\subsection{Source of tree stem $\mathrm{N}_{2} \mathrm{O}$ emissions and their contribution to total (stem + soil) $\mathrm{N}_{2} \mathrm{O}$ emissions}

Emitted $\mathrm{N}_{2} \mathrm{O}$ from stems was found to originate predominantly from $\mathrm{N}_{2} \mathrm{O}$ produced in the soil, as shown by the ${ }^{15} \mathrm{~N}-$ tracing experiment (Fig. 3). Additionally, the positive correlations of stem $\mathrm{N}_{2} \mathrm{O}$ emissions with soil-air $\mathrm{N}_{2} \mathrm{O}$ concentrations and soil $\mathrm{N}_{2} \mathrm{O}$ emissions (Table 3) suggest that the seasonal variation in stem $\mathrm{N}_{2} \mathrm{O}$ emissions (Table A3; Fig. 2) was likely driven by the temporal dynamics of produced $\mathrm{N}_{2} \mathrm{O}$ in the soil, which partly supported our second hypothesis. While there have been suggestions of within-tree $\mathrm{N}_{2} \mathrm{O}$ production (e.g., Lenhart et al., 2019), our finding from the ${ }^{15} \mathrm{~N}$ tracing experiment, combined with the correlations of stem $\mathrm{N}_{2} \mathrm{O}$ emissions with VPD and air temperature, pointed to a transport mechanism of dissolved $\mathrm{N}_{2} \mathrm{O}$ in soil water by transpiration stream, which has been reported to be important for 
upland trees that do not have aerenchyma (Machacova et al., 2016; Welch et al., 2019; Wen et al., 2017).

The contributions of up-scaled stem $\mathrm{N}_{2} \mathrm{O}$ emissions from our studied forests to total (stem + soil) $\mathrm{N}_{2} \mathrm{O}$ emissions (Table 2) were higher than those reported for temperate forests (1\%-18\%; Díaz-Pinés et al., 2016; Machacova et al., 2016; Wen et al., 2017). Given the higher stem $\mathrm{N}_{2} \mathrm{O}$ emissions in the wet than dry seasons (Table A3), coupled with the fact that we consistently measured positive fluxes or net stem $\mathrm{N}_{2} \mathrm{O}$ emissions throughout our measurement period (Fig. 2), we conclude that tree stems in these well-drained Ferralsol soils were efficient conduits for releasing $\mathrm{N}_{2} \mathrm{O}$ from the soil. This has significant implications in particular during the rainy season as this pathway bypasses the chance for complete denitrification $\left(\mathrm{N}_{2} \mathrm{O}\right.$ to $\mathrm{N}_{2}$ reduction) in the soil.

\subsection{Factors controlling temporal variability of stem and soil $\mathrm{N}_{2} \mathrm{O}$ fluxes}

The positive correlation of stem $\mathrm{N}_{2} \mathrm{O}$ emissions with VPD and air temperature in the forest suggests transport of $\mathrm{N}_{2} \mathrm{O}$ via sap flow, for which the sap flow had been shown to be stimulated with increasing VPD and air temperature (McJannet et al., 2007; O'Brien et al., 2004). Soil water containing dissolved $\mathrm{N}_{2} \mathrm{O}$ is transported through the xylem via the transpiration stream and eventually emitted from the stem surface to the atmosphere (Díaz-Pinés et al., 2016; Welch et al., 2019; Wen et al., 2017).

Soil moisture has been shown to strongly affect the seasonal variation in soil $\mathrm{N}_{2} \mathrm{O}$ emissions from tropical ecosystems, with increases in soil $\mathrm{N}_{2} \mathrm{O}$ emissions by predominantly the denitrification process at high WFPS (Corre et al., 2014; Koehler et al., 2009; Matson et al., 2017; Werner et al., 2006). The larger stem $\mathrm{N}_{2} \mathrm{O}$ emissions from the forest and soil $\mathrm{N}_{2} \mathrm{O}$ emissions from both land uses in the wet season than the dry season (Tables $\mathrm{S} 2, \mathrm{~S} 3$ ) signified favourable soil $\mathrm{N}_{2} \mathrm{O}$ production during the wet season, which suggests that denitrification was the dominant $\mathrm{N}_{2} \mathrm{O}$-producing process. However, the moderate WFPS across the year (Table 4) suggests that nitrification may also have contributed to $\mathrm{N}_{2} \mathrm{O}$ emissions, especially at Biba Yezoum (with lower rainfall and clay contents; Tables 1, S1) where the low WFPS (Table 4) likely favoured nitrification (Corre et al., 2014). For the forest, the negative correlation of the stem and soil $\mathrm{N}_{2} \mathrm{O}$ emissions with soil $\mathrm{NH}_{4}^{+}$(Tables $3, \mathrm{~S} 2$ ) may be indicative of a conservative soil $\mathrm{N}$ cycle at our forest sites, as supported by the dominance of soil $\mathrm{NH}_{4}^{+}$over $\mathrm{NO}_{3}^{-}$(Table 2) and by the lower soil $\mathrm{N}_{2} \mathrm{O}$ emissions at our sites compared to $\mathrm{NO}_{3}^{-}$-dominated systems (Davidson et al., 2000). Although the soil mineral $\mathrm{N}$ content alone does not indicate the $\mathrm{N}$-supplying capacity of the soil, the relative contents of $\mathrm{NH}_{4}^{+}$over $\mathrm{NO}_{3}^{-}$can be a good indicator of whether the soil $\mathrm{N}$ cycling is conservative with low $\mathrm{N}_{2} \mathrm{O}$ losses or increasingly leaky (Corre et al., 2010, 2014).

\subsection{Land-use change effects on soil $\mathrm{N}_{2} \mathrm{O}$ emissions}

The annual soil $\mathrm{N}_{2} \mathrm{O}$ emissions from CAF (Table 2) were comparable with those reported for rubber agroforestry in Indonesia $\left(0.6-1.2 \mathrm{~kg} \mathrm{~N} \mathrm{ha}^{-1} \mathrm{yr}^{-1}\right.$; Hassler et al., 2017) and from multistrata agroforestry systems in Peru (0.6 kg N ha ${ }^{-1} \mathrm{yr}^{-1}$; Palm et al., 2002). However, our soil $\mathrm{N}_{2} \mathrm{O}$ emissions from $\mathrm{CAF}$ were higher than those from an extensively managed home garden in Tanzania (0.35 $\mathrm{N} \mathrm{ha}^{-1} \mathrm{yr}^{-1}$; Gütlein et al., 2018). In a review, Kim et al. (2016a) reported mean annual $\mathrm{N}_{2} \mathrm{O}$ emission from agroforestry systems to be $7.7 \mathrm{~kg} \mathrm{Nha}^{-1} \mathrm{yr}^{-1}$. Most of the data used in their review were from intensively managed agroforestry systems with varied fertilizer inputs, which were absent in our extensively managed CAF systems. In line with this, our measured soil $\mathrm{N}_{2} \mathrm{O}$ emissions from the CAF were also lower than the emissions reported for 10-23-yearold CAF in Indonesia $\left(3.1 \mathrm{~kg} \mathrm{Nha}^{-1} \mathrm{yr}^{-1}\right.$; Veldkamp et al., 2008). Our measured $\mathrm{N}_{2} \mathrm{O}$ emissions provide the first estimates for traditional CAF systems in Africa, as these production systems were not represented in extrapolation of $\mathrm{GHG}$ budgets despite their extensive coverage in Africa.

Soil $\mathrm{N}_{2} \mathrm{O}$ emissions did not differ between forest and CAF systems, which supported our first hypothesis. This is possibly due to the presence of leguminous trees in both systems (Table A1), which can compensate for $\mathrm{N}$ export from harvest and other losses (Erickson et al., 2002; Veldkamp et al., 2008). Although studies have hinted at increased $\mathrm{N}_{2} \mathrm{O}$ emissions from managed systems that utilize leguminous trees as cover crops (Veldkamp et al., 2008), the similar abundance of leguminous trees between forest and CAF at our sites may have offset this effect (Table A1). Previous studies have indeed reported similar soil $\mathrm{N}_{2} \mathrm{O}$ fluxes between reference forests and unfertilized agroforestry systems (van Lent et al., 2015). Despite the general absence of heavy soil physical disturbance, cultivation and fertilization in these traditional CAF systems, some soil biochemical characteristics have decreased (Table 1); however, these did not translate into detectable differences in soil $\mathrm{N}_{2} \mathrm{O}$ emissions from those from forest.

\subsection{Implications}

The biophysical conditions of our forest sites were representative of approximately two-thirds of the rainforest area in the Congo Basin $\left(1.137 \times 10^{6} \mathrm{~km}^{2}\right.$; Fig. B3), considering the same Ferralsol soils, similar elevation $(\leq 1000 \mathrm{~m}$ a.s.l.), and annual rainfall between 1500 and $2100 \mathrm{~mm} \mathrm{yr}^{-1}$. Using the total (soil + stem) $\mathrm{N}_{2} \mathrm{O}$ emission from our forest sites ( $1.55 \pm 0.20 \mathrm{~N}_{2} \mathrm{O}-\mathrm{N} \mathrm{kg} \mathrm{ha}{ }^{-1} \mathrm{yr}^{-1}$; Table 2$)$, our extrapolated emission for two-thirds of the Congo Basin was $0.18 \pm 0.05 \mathrm{Tg} \mathrm{N}_{2} \mathrm{O}-\mathrm{N} \mathrm{yr}^{-1}$ (error estimate is the $95 \%$ confidence interval). This accounted for $52 \%$ of the earlier estimate of soil $\mathrm{N}_{2} \mathrm{O}$ emissions from tropical rainforests in Africa $\left(0.34 \mathrm{Tg} \mathrm{N}_{2} \mathrm{O}-\mathrm{N} \mathrm{yr}^{-1}\right.$; Werner et al., 2007a), or 
$25 \%$ based on a more recent estimate $\left(0.72 \mathrm{Tg} \mathrm{N}_{2} \mathrm{O}-\mathrm{N} \mathrm{yr}^{-1}\right.$; Valentini et al., 2014). We acknowledge, however, that there are uncertainties in our extrapolation (as is the case of these cited estimates) because our up-scaling approach from plot to regional level did not account for the spatial variability of large-scale drivers of soil $\mathrm{N}_{2} \mathrm{O}$ emissions, such as soil texture, landforms and vegetation characteristics. These limitations of our estimate of $\mathrm{N}_{2} \mathrm{O}$ source strength for the Congo Basin rainforests call for further investigations in Africa to address the geographic bias of studies in the tropical region (e.g., Powers et al., 2011). The most important consideration in the bottom-up spatial extrapolation approach is to recognize at the outset that the design of the field quantification must reflect the landscape-scale drivers of the studied process; e.g. land-use types (reflecting management), soil texture (as a surrogate of parent material) and climate are landscape-scale controllers of soil N, C and GHG fluxes (e.g., Corre et al., 1999; Hassler et al., 2017; Silver et al., 2000; Veldkamp et al., 2008, 2013), whereas topography (reflecting soil types, moisture regimes, fertility) is the main driver within a landscape (e.g., Corre et al., 1996, 2002; Groffman and Tiedje, 1989; Pennock and Corre, 2001). Process-based models and geographic information system databases can be combined with field-based measurements for improved extrapolation.

Our year-round measurements of stem and soil $\mathrm{N}_{2} \mathrm{O}$ fluxes were the first detailed study carried out in the Congo Basin, with key implications on improved estimates of $\mathrm{N}_{2} \mathrm{O}$ budget for Africa. Our results revealed that trees on well-drained, highly weathered soils served as an important $\mathrm{N}_{2} \mathrm{O}$ emission pathway, with the potential to overlook up to $38 \%$ of $\mathrm{N}_{2} \mathrm{O}$ emissions if trees are not considered in the ecosystem $\mathrm{N}_{2} \mathrm{O}$ budget. Our measured tree species spanned different life history strategies and functional traits (a mixture of pioneers, non-pioneer light demanders and shade tolerants; Table A2); the lack of species-specific differences suggests that our findings could be more widely generalizable across communities with different species compositions, at least from highly weathered soils. However, the narrow range of tree DBH classes of our measured trees may have important implications for stands of different successional stages or ages, as stem diameter size, wood density and other physiological characteristics may possibly influence stem $\mathrm{N}_{2} \mathrm{O}$ fluxes (Machacova et al., 2019; Welch et al., 2019). Also, the possibility of large $\mathrm{N}_{2} \mathrm{O}$ fluxes at the stem base near the ground (Barba et al., 2019; Welch et al., 2019), which we could not measure due to irregular surface of buttresses, warrants further investigation. All this combined may imply that our quantified stem $\mathrm{N}_{2} \mathrm{O}$ emissions result in a conservative estimate of the overall stem $\mathrm{N}_{2} \mathrm{O}$ budget from this important region. Forest conversion to traditional, mature ( $>20$ years old) CAF systems had no effect on stem and soil $\mathrm{N}_{2} \mathrm{O}$ emissions because of similarities in soil moisture and soil texture, absence of fertilizer application, and comparable abundance of leguminous trees in both land uses, which can compen- sate for $\mathrm{N}$ export from harvest or other losses. Further multitemporal and spatially replicated studies are needed to provide additional insights into the effect of forest conversion to other land uses on GHG fluxes from the African continent in order to improve GHG budget estimations for the region. 


\section{Appendix A}

Table A1. Vegetation and site characteristics of the study sites on highly weathered soils in the Congo Basin, Cameroon. All vegetation characteristics were determined from trees with $\geq 10 \mathrm{~cm}$ diameter at breast height in both forest and cacao agroforestry.

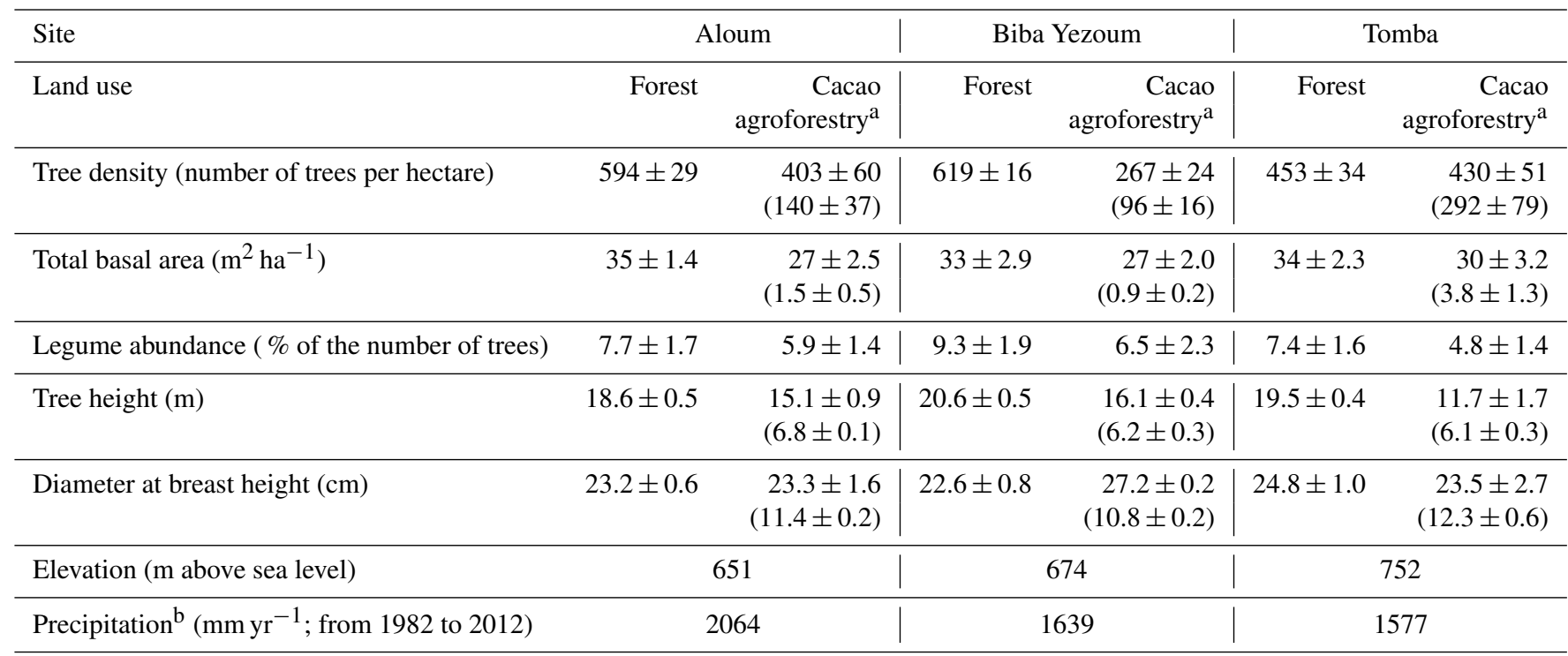

${ }^{a}$ For cacao agroforestry, the first values are for both cacao and remnant shade trees, and the second values in parentheses are for cacao trees only. ${ }^{\mathrm{b}}$ Climate-Data.org (2019). 
Table A2. Ecological and functional traits of the measured trees, selected from the most dominant tree species at each site, based on their importance value index (IVI is equal to relative density plus relative frequency plus relative dominance; Curtis and McIntosh, 1951). For a given species, the relative density refers to its total number of individuals in the four forest plots at each site, the relative frequency refers to its occurrence among the four forest plots and the relative dominance refers to its total basal area in the four forest plots, all expressed as percentages of all species.

\begin{tabular}{|c|c|c|c|c|}
\hline Site & Guild $^{\mathrm{a}}$ & Phenology & Dispersal & Wood density $^{b}$ \\
\hline \multicolumn{5}{|l|}{ Aloum } \\
\hline Allanblackia floribunda & SB & Evergreen & Zoochore & 0.69 \\
\hline Anthonotha macrophylla & $\mathrm{SB}$ & Evergreen & - & 0.83 \\
\hline Cleistopholis patens & Pioneer & Deciduous & Zoochore & 0.34 \\
\hline Coelocaryon preussi & NPLD & Evergreen & Zoochore & 0.50 \\
\hline Desbordesia insignis & SB & Evergreen & Anemochore & 0.92 \\
\hline Parkia bicolor & NPLD & Deciduous & Zoochore & 0.45 \\
\hline Plagiostyles africana & $\mathrm{SB}$ & Evergreen & Zoochore & 0.75 \\
\hline Pycnanthus angolensis & NPLD & Evergreen & Zoochore & 0.41 \\
\hline Staudtia kamerunensis & SB & Evergreen & Zoochore & 0.79 \\
\hline Theobroma cacao & Sub-canopy & Evergreen & & 0.42 \\
\hline \multicolumn{5}{|l|}{ Biba Yezoum } \\
\hline Carapa procera & SB & Evergreen & Zoochore & 0.60 \\
\hline Celtis sp. & $\mathrm{NPLD}+\mathrm{SB}$ & Deciduous + evergreen & Zoochore & 0.59 \\
\hline Diospyros sp. & SB & Deciduous & Zoochore & 0.70 \\
\hline Entandrophragma candollei & NPLD & Deciduous & Anemochore & 0.57 \\
\hline Eribroma oblongum & SB & Deciduous & Zoochore & 0.64 \\
\hline Lovoa trichilioides & NPLD & Evergreen & Anemochore & 0.46 \\
\hline Petersianthus macrocarpus & Pioneer & Deciduous + evergreen & Anemochore & 0.68 \\
\hline Theobroma cacao & Sub-canopy & Evergreen & & 0.42 \\
\hline \multicolumn{5}{|l|}{ Tomba } \\
\hline Annickia chlorantha & $\mathrm{SB}$ & Evergreen & Zoochore & 0.44 \\
\hline Anonidium mannii & SB & Evergreen & Zoochore & 0.29 \\
\hline Carapa procera & SB & Evergreen & Zoochore & 0.60 \\
\hline Celtis sp. & $\mathrm{NPLD}+\mathrm{SB}$ & Deciduous + evergreen & Zoochore & 0.59 \\
\hline Funtumia elastica & NPLD & Evergreen & Anemochore & 0.42 \\
\hline Leonardoxa africana & SB & - & - & - \\
\hline Lovoa trichilioides & NPLD & Evergreen & Anemochore & 0.46 \\
\hline Markhamia lutea & Pioneer & Evergreen & Anemochore & 0.50 \\
\hline Mitragyna stipulosa & Pioneer & Evergreen & Anemochore & 0.47 \\
\hline Pycnanthus angolensis & NPLD & Evergreen & Zoochore & 0.41 \\
\hline Theobroma cacao & Sub-canopy & Evergreen & & 0.42 \\
\hline
\end{tabular}

${ }^{a}$ Each species was assigned to one of the three regeneration guilds defined by Hawthorne (1995): SB: shade-bearer; NPLD: non-pioneer light demander; P: pioneer. ${ }^{b}$ Global Wood Density Database (Brown, 1997; Zanne et al., 2009). 
Table A3. Seasonal mean ( \pm SE, $n=4$ ) water-filled pore space (WFPS), extractable mineral N (measured in the top $5 \mathrm{~cm}$ of soil) and nitrous oxide $\left(\mathrm{N}_{2} \mathrm{O}\right)$ fluxes in forests on highly weathered soils in the Congo Basin, Cameroon. Means followed by different lowercase letters indicate significant differences between seasons for each site (linear mixed-effect models with Tukey's HSD at $P \leq 0.05$ ).

\begin{tabular}{lrrrrr}
\hline Season/site & $\begin{array}{r}\text { Stem } \mathrm{N}_{2} \mathrm{O} \text { flux } \\
\left(\mu \mathrm{g} \mathrm{N} \mathrm{m}^{-2} \mathrm{stem}^{-1}\right)\end{array}$ & $\begin{array}{r}\text { Soil } \mathrm{N}_{2} \mathrm{O} \text { flux } \\
\left(\mu \mathrm{g} \mathrm{N} \mathrm{m}^{-2} \mathrm{soil} \mathrm{h}^{-1}\right)\end{array}$ & $\begin{array}{r}\text { WFPS } \\
(\%)\end{array}$ & $\begin{array}{r}\mathrm{Soil} \mathrm{NH}_{4}^{+} \\
\left(\mathrm{mg} \mathrm{N} \mathrm{kg}^{-1}\right)\end{array}$ & $\begin{array}{r}\mathrm{Soil} \mathrm{NO}_{3}^{-} \\
\left(\mathrm{mg} \mathrm{N} \mathrm{kg}^{-1}\right)\end{array}$ \\
\hline Wet season & & & & & \\
\hline Aloum & $1.56 \pm 0.36^{\mathrm{a}}$ & $16.7 \pm 3.7^{\mathrm{a}}$ & $66.2 \pm 2.2^{\mathrm{a}}$ & $6.0 \pm 0.6^{\mathrm{a}}$ & $6.0 \pm 0.8^{\mathrm{a}}$ \\
Biba Yezoum & $2.92 \pm 0.73^{\mathrm{a}}$ & $22.9 \pm 4.9^{\mathrm{a}}$ & $44.8 \pm 2.6^{\mathrm{a}}$ & $4.4 \pm 0.3^{\mathrm{a}}$ & $2.2 \pm 0.2^{\mathrm{b}}$ \\
Tomba & $1.01 \pm 0.13^{\mathrm{a}}$ & $18.6 \pm 2.2^{\mathrm{a}}$ & $49.4 \pm 1.8^{\mathrm{a}}$ & $6.9 \pm 0.5^{\mathrm{b}}$ & $5.4 \pm 0.8^{\mathrm{a}}$ \\
\hline Dry season & & & & \\
\hline Aloum & $0.61 \pm 0.14^{\mathrm{b}}$ & $10.0 \pm 1.8^{\mathrm{b}}$ & $62.0 \pm 3.6^{\mathrm{a}}$ & $8.7 \pm 1.3^{\mathrm{a}}$ & $6.6 \pm 1.0^{\mathrm{a}}$ \\
Biba Yezoum & $1.73 \pm 0.57^{\mathrm{b}}$ & $10.3 \pm 1.4^{\mathrm{b}}$ & $36.3 \pm 3.2^{\mathrm{a}}$ & $5.5 \pm 0.4^{\mathrm{a}}$ & $3.6 \pm 0.5^{\mathrm{a}}$ \\
Tomba & $0.69 \pm 0.15^{\mathrm{b}}$ & $8.9 \pm 1.9^{\mathrm{b}}$ & $46.2 \pm 3.1^{\mathrm{a}}$ & $8.7 \pm 0.8^{\mathrm{a}}$ & $6.5 \pm 1.1^{\mathrm{a}}$ \\
\hline
\end{tabular}

Table A4. Seasonal mean ( \pm SE, $n=4$ ) water-filled pore space (WFPS), extractable mineral N (measured in the top $5 \mathrm{~cm}$ of soil) and nitrous oxide $\left(\mathrm{N}_{2} \mathrm{O}\right)$ fluxes in cacao agroforestry sites located on highly weathered soils in the Congo Basin, Cameroon. Means followed by different lowercase letters indicate significant differences between seasons for each site (linear mixed-effect models with Tukey's HSD at $P \leq 0.05$ ).

\begin{tabular}{lcrrrr}
\hline Site/season & $\begin{array}{r}\text { Stem } \mathrm{N}_{2} \mathrm{O} \text { flux } \\
\left(\mu \mathrm{g} \mathrm{m}^{-2} \mathrm{stem}^{-1}\right)\end{array}$ & $\begin{array}{r}\text { Soil } \mathrm{N}_{2} \mathrm{O} \text { flux } \\
\left(\mu \mathrm{N} \mathrm{m}^{-2} \mathrm{soil}^{-1}\right)\end{array}$ & $\begin{array}{r}\text { WFPS } \\
(\%)\end{array}$ & $\begin{array}{r}\text { Soil NH }_{4}^{+} \\
\left(\mathrm{mg} \mathrm{N} \mathrm{kg}^{-1}\right)\end{array}$ & $\begin{array}{r}\text { Soil NO }_{3}^{-} \\
\left(\mathrm{mg} \mathrm{kg} \mathrm{k}^{-1}\right)\end{array}$ \\
\hline Wet season & $1.21 \pm 0.27^{\mathrm{a}}$ & $22.6 \pm 4.7^{\mathrm{a}}$ & $60.3 \pm 1.6^{\mathrm{a}}$ & $4.3 \pm 0.4^{\mathrm{a}}$ & $2.1 \pm 0.4^{\mathrm{a}}$ \\
\hline Aloum & $1.43 \pm 0.36^{\mathrm{a}}$ & $15.0 \pm 3.5^{\mathrm{a}}$ & $38.2 \pm 1.7^{\mathrm{a}}$ & $7.0 \pm 0.6^{\mathrm{a}}$ & $2.2 \pm 0.4^{\mathrm{a}}$ \\
Biba Yezoum & $1.05 \pm 0.18^{\mathrm{a}}$ & $21.2 \pm 2.6^{\mathrm{a}}$ & $53.4 \pm 2.4^{\mathrm{a}}$ & $7.3 \pm 0.8^{\mathrm{a}}$ & $2.5 \pm 0.3^{\mathrm{a}}$ \\
Tomba & & & & & \\
\hline Dry season & $0.53 \pm 0.07^{\mathrm{b}}$ & $6.4 \pm 0.7^{\mathrm{b}}$ & $51.7 \pm 1.9^{\mathrm{b}}$ & $6.0 \pm 1.0^{\mathrm{a}}$ & $2.7 \pm 0.6^{\mathrm{a}}$ \\
\hline Aloum & $0.74 \pm 0.12^{\mathrm{a}}$ & $5.3 \pm 1.3^{\mathrm{b}}$ & $25.9 \pm 1.8^{\mathrm{b}}$ & $7.5 \pm 0.6^{\mathrm{a}}$ & $3.2 \pm 0.7^{\mathrm{a}}$ \\
Biba Yezoum & $0.63 \pm 0.06^{\mathrm{a}}$ & $6.2 \pm 1.2^{\mathrm{b}}$ & $50.4 \pm 6.2^{\mathrm{a}}$ & $6.9 \pm 0.9^{\mathrm{a}}$ & $3.4 \pm 0.7^{\mathrm{a}}$ \\
Tomba & & & & & \\
\hline
\end{tabular}




\section{Appendix B}

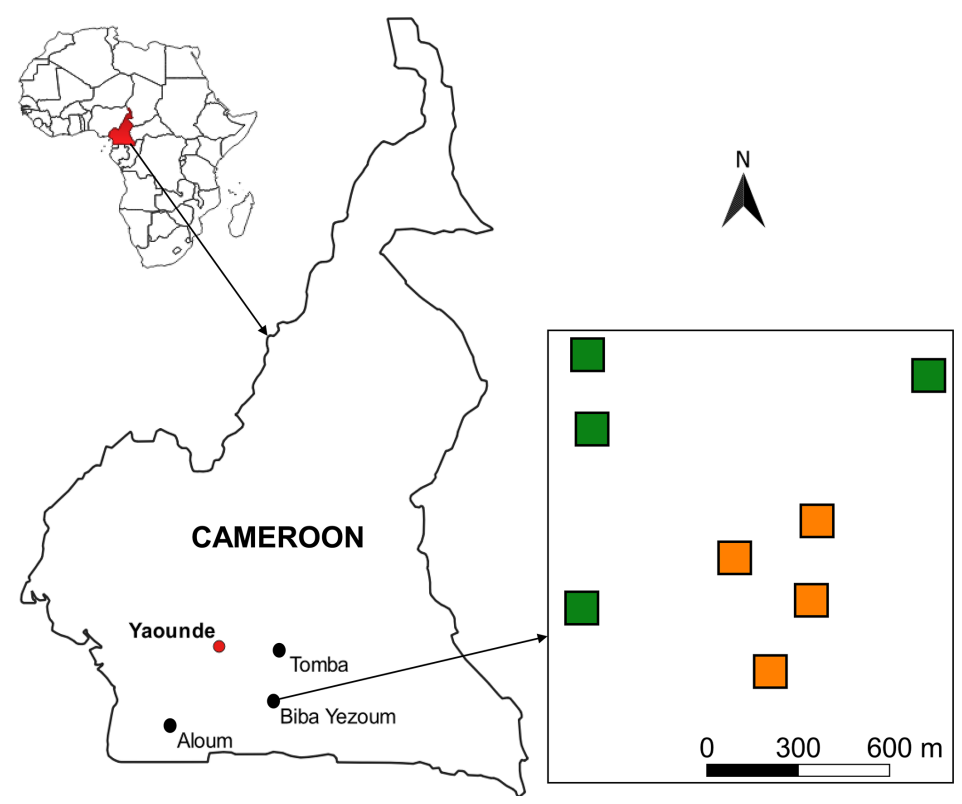

Figure B1. Location of the study sites in Cameroon, showing the four replicate plots per land use (green for forests and orange for cacao agroforestry) at one site.

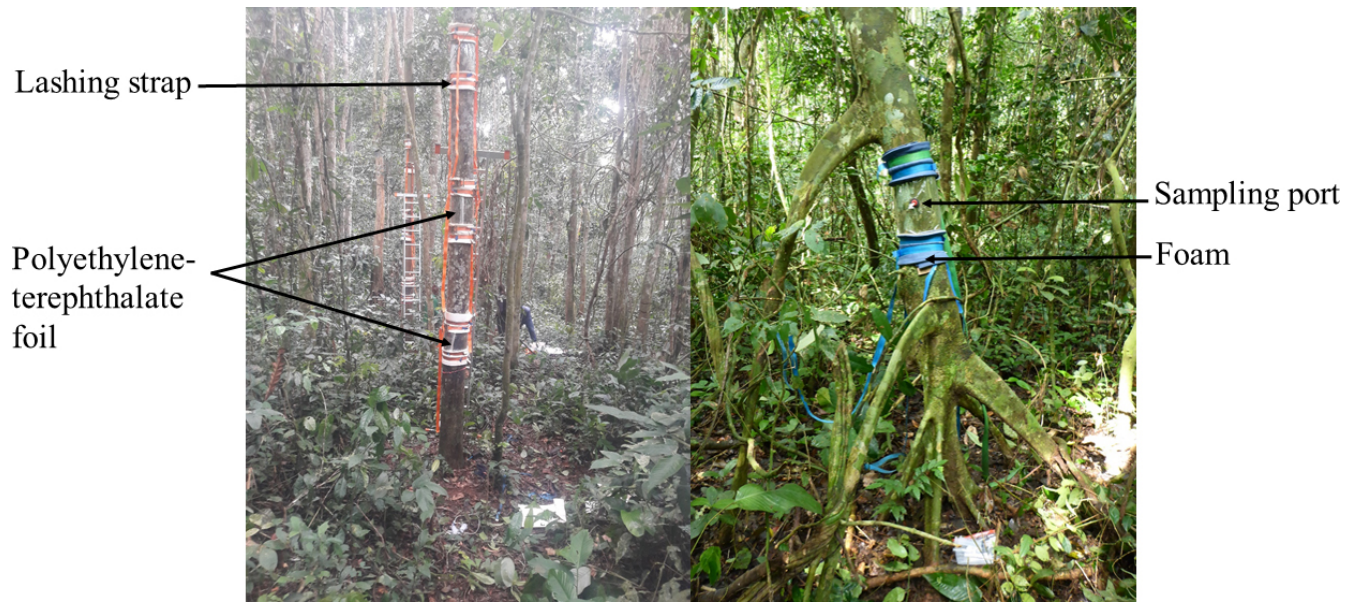

Figure B2. Sampling set-up for stem nitrous oxide $\left(\mathrm{N}_{2} \mathrm{O}\right)$-flux measurement at three stem heights in a rainforest in the Congo Basin, Cameroon. 


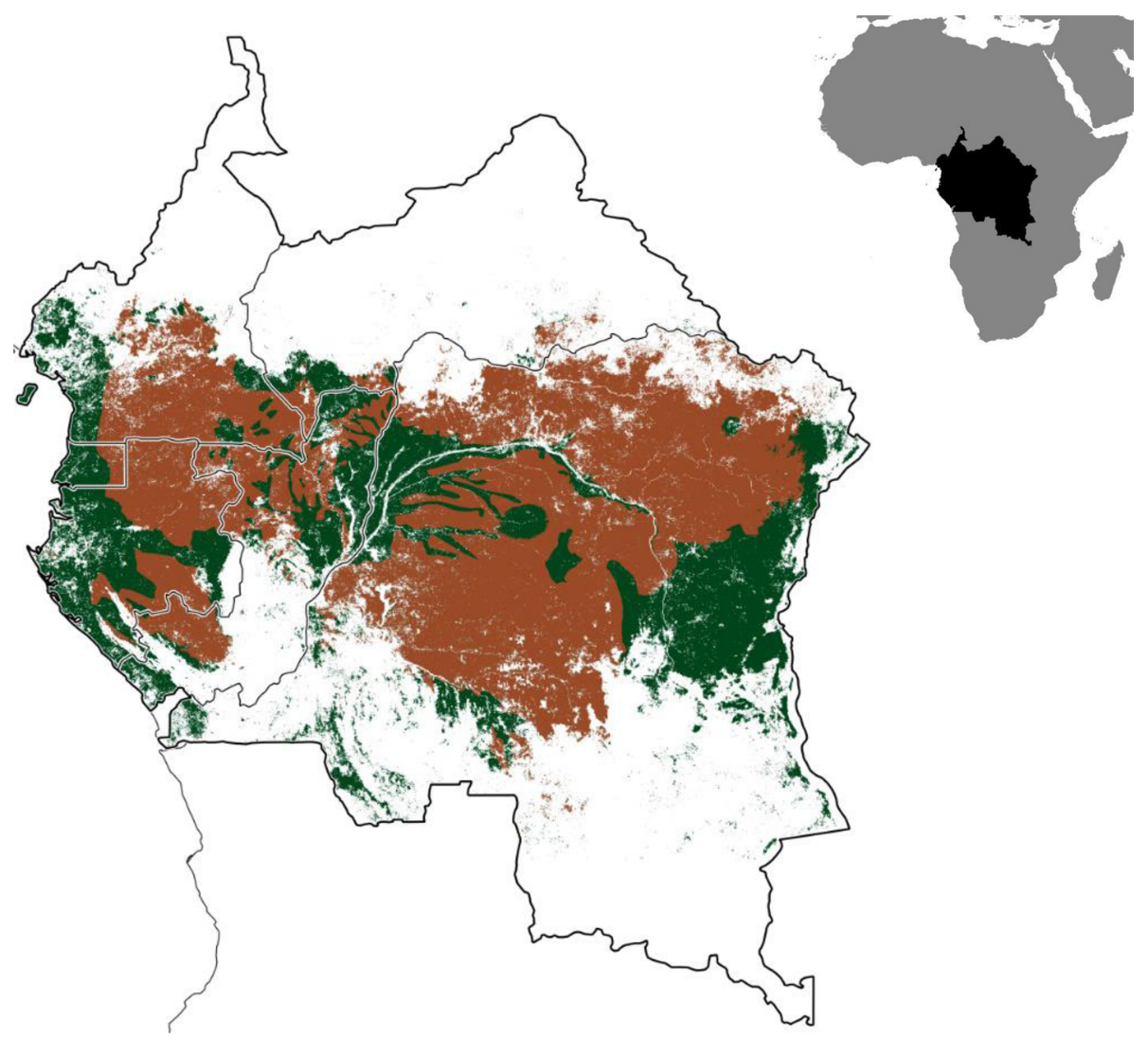

Figure B3. Map of the Congo Basin rainforest (green) spanning across the six major Congo Basin countries. The brown shaded area represents the proportion of the Congo rainforest with biophysical conditions similar to those in our study sites (Ferralsol soils, $\leq 1000 \mathrm{~m}$ elevation and $1500-2100 \mathrm{~mm} \mathrm{yr}^{-1}$ precipitation). 
Data availability. Data are available from the Göttingen Research Online repository: https://doi.org/10.25625/T2CGYM (Iddris et al., 2020).

Author contributions. EV and MDC conceived the research project; NAAI carried out fieldwork and analysed data; NAAI and OvS performed GIS analysis; NAAI and MDC interpreted data and wrote the paper; EV, OvS and MY revised the draft paper.

Competing interests. The authors declare that they have no conflict of interest.

Acknowledgements. We gratefully acknowledge our counterparts in Cameroon, the International Institute for Tropical Agriculture (IITA) for granting us access to and use of their storage facilities. We are especially grateful to our Cameroonian field assistants Leonel Boris Gadjui Youatou, Narcis Lekeng, Yannick Eyenga Alfred, Denis Djiyo and all the fieldworkers for their great support with field measurements as well as Raphael Manu for helping with the GIS work and Rodine Tchiofo Lontsi for many discussions on soil processes and Cameroonian settings. We also thank the village leaders and local plot owners for granting us access to their forest and cacao farms. We thank Andrea Bauer, Kerstin Langs, Martina Knaust and Lars Szwec for their assistance with laboratory analyses.

Financial support. This research has been supported by the Deutsche Forschungsgemeinschaft (grant nos. VE 219/14-1 and STR 1375/1-1).

Review statement. This paper was edited by Lutz Merbold and reviewed by Yit Arn Teh and Vincent Gauci.

\section{References}

Allen, R. G., Pereira, L. S., Raes, D., and Smith, M.: Determination of $\mathrm{ET}_{0}$, crop evapotranspiration, Guidel. Comput. Crop Water Requir. Irrig. Drain. Pap. 56, 300 pp., available at: http://www. hidmet.gov.rs/podaci/agro/tableofcontens_files.pdf (last access: 3 May 2019), 1998.

Barba, J., Poyatos, R., and Vargas, R.: Automated measurements of greenhouse gases fluxes from tree stems and soils: magnitudes, patterns and drivers, Sci. Rep.-UK, 9, 1-13, https://doi.org/10.1038/s41598-019-39663-8, 2019.

Bouwman, A. F., Van Der Hoek, K. W., and Olivier, J. G. J.: Uncertainties in the global source distribution of nitrous oxide, J. Geophys. Res., 100, 2785-2800, https://doi.org/10.1029/94JD02946, 1995.

Breuer, L., Papen, H., and Butterbach-Bahl, K.: $\mathrm{N}_{2} \mathrm{O}$ emission from tropical forest soils of Australia, J. Geophys. Res.-Atmos., 105, 26353-26367, https://doi.org/10.1029/2000JD900424, 2000.
Brown, S.: Estimating biomass and biomass change of tropical forests: a primer, UN FAO Forestry Paper 134, FAO, Rome, 1997.

Castaldi, S., Bertolini, T., Valente, A., Chiti, T., and Valentini, R.: Nitrous oxide emissions from soil of an African rain forest in Ghana, Biogeosciences, 10, 4179-4187, https://doi.org/10.5194/bg-10-4179-2013, 2013.

Climate-Data.org: Cameroon climate, available at: https://en. climate-data.org/africa/cameroon-142/, last access: 21 May 2019.

Corre, M. D., van Kessel, C., and Pennock, D. J.: Landscape and Seasonal Patterns of Nitrous Oxide Emissions in a Semiarid Region, Soil Sci. Soc. Am. J., 60, 1806-1815, https://doi.org/10.2136/sssaj1996.03615995006000060028x, 1996.

Corre, M. D., Pennock, D. J., Van Kessel, C., and Elliott, D. K.: Estimation of annual nitrous oxide emissions from a transitional grassland-forest region in Saskatchewan, Canada, Biogeochemistry, 44, 29-49, https://doi.org/10.1023/A:1006025907180, 1999.

Corre, M. D., Schnabel, R. R., and Stout, W. L.: Spatial and seasonal variation of gross nitrogen transformations and microbial biomass in a Northeastern US grassland, Soil Biol. Biochem., 34, 445-457, https://doi.org/10.1016/S0038-0717(01)00198-5, 2002.

Corre, M. D., Dechert, G., and Veldkamp, E.: Soil nitrogen cycling following montane forest conversion in Central Sulawesi, Indonesia, Soil Sci. Soc. Am. J., 70, 359-366, https://doi.org/10.2136/sssaj2005.0061, 2006.

Corre, M. D., Veldkamp, E., Arnold, J., and Joseph Wright, S.: Impact of elevated $\mathrm{N}$ input on soil $\mathrm{N}$ cycling and losses in oldgrowth lowland and montane forests in Panama, Ecology, 91, 1715-1729, https://doi.org/10.1890/09-0274.1, 2010.

Corre, M. D., Sueta, J. P., and Veldkamp, E.: Nitrogen-oxide emissions from tropical forest soils exposed to elevated nitrogen input strongly interact with rainfall quantity and seasonality, Biogeochemistry, 118, 103-120, https://doi.org/10.1007/s10533013-9908-3, 2014.

Crawley, M. J.: The R Book, John Wiley \& Sons Ltd, Chichester, UK, 2009.

Curtis, J. T. and McIntosh, R. P.: An Upland Forest Continuum in the Prairie-Forest Border Region of Wisconsin, Ecology, 32, 476-496, https://doi.org/10.2307/1931725, 1951.

Davidson, E. A. and Kanter, D.: Inventories and scenarios of nitrous oxide emissions, Environ. Res. Lett., 9, 105012, https://doi.org/10.1088/1748-9326/9/10/105012, 2014.

Davidson, E. A. and Verchot, L. V.: Testing the hole-in-the-pipe model of nitric and nitrous oxide emissions from soils using the TRAGNET database, Global Biogeochem. Cy., 14, 1035-1043, https://doi.org/10.1029/1999GB001223, 2000.

Davidson, E. A., Keller, M., Erickson, H. E., Verchot, L. V., and Veldkamp, E.: Testing a Conceptual Model of Soil Emissions of Nitrous and Nitric Oxides, Bioscience, 50, 667, https://doi.org/10.1641/00063568(2000)050[0667:tacmos]2.0.co;2, 2000.

Denman, K. L., Brasseur, G., Chidthaisong, A., Ciais, P., Cox, P. M., Dickinson, R. E., Hauglustaine, D., Heinze, C., Holland, E., Jacob, D., Lohmann, U., Ramachandran, S., da Silva Dias, P. L., Wofsy, S. C., and Zhang, X.: Couplings Between 
Changes in the Climate System and Biogeochemistry, in Climate Change 2007: The Physical Science Basis. Contribution of Working Group I to the Fourth Assessment Report of the Intergovernmental Panel on Climate Change, Cambridge University Press, Cambridge, United Kingdom and New York, NY, USA, available at: https://www.ipcc.ch/site/assets/uploads/2018/ 02/ar4-wg1-chapter7-1.pdf (last access: 24 July 2019), 2007.

Díaz-Pinés, E., Heras, P., Gasche, R., Rubio, A., Rennenberg, H., Butterbach-Bahl, K., and Kiese, R.: Nitrous oxide emissions from stems of ash (Fraxinus angustifolia Vahl) and European beech (Fagus sylvatica L.), Plant Soil, 398, 35-45, https://doi.org/10.1007/s11104-015-2629-8, 2016.

Dkamela, G. P.: The context of REDD+ in Cameroon: Drivers, agents and institutions, Occasional., CIFOR, Bogor, Indonesia, 2010.

Erickson, H. E., Davidson, E. A., and Keller, M.: Former land-use and tree species affect nitrogen oxide emissions from a tropical dry forest, Oecologia, 130, 297-308, https://doi.org/10.1007/s004420100801, 2002.

FAO/IIASA/ISRIC/ISS-CAS/JRC: Harmonized World Soil Database (version 1.2), FAO, Rome, Italy and IIASA, Laxenburg, Austria, available at: http://webarchive.iiasa.ac.at/ Research/LUC/External-World-soil-database/HTML/ (last access: 13 September 2019), 2012.

Groffman, P. M. and Tiedje, J. M.: Denitrification in north temperate forest soils: Spatial and temporal patterns at the landscape and seasonal scales, Soil Biol. Biochem., 21, 613-620, https://doi.org/10.1016/0038-0717(89)90053-9, 1989.

Groffman, P. M., Brumme, R., Butterbach-Bahl, K., Dobbie, K. E., Mosier, A. R., Ojima, D., Papen, H., Parton, W. J., Smith, K. A., and Wagner-Riddle, C.: Evaluating annual nitrous oxide fluxes at the ecosystem scale, Global Biogeochem. Cy., 14, 1061-1070, https://doi.org/10.1029/1999GB001227, 2000.

Gütlein, A., Gerschlauer, F., Kikoti, I., and Kiese, R.: Impacts of climate and land use on $\mathrm{N}_{2} \mathrm{O}$ and $\mathrm{CH}_{4}$ fluxes from tropical ecosystems in the Mt. Kilimanjaro region, Tanzania, Glob. Change Biol., 24, 1239-1255, https://doi.org/10.1111/gcb.13944, 2018.

Gwanfogbe, M., Meligui, A., Moukam, J., and Nguoghia, J.: Geography of Cameroon, Macmillan Education Ltd, Hong Kong, 1983.

Hassler, E., Corre, M. D., Tjoa, A., Damris, M., Utami, S. R., and Veldkamp, E.: Soil fertility controls soil-atmosphere carbon dioxide and methane fluxes in a tropical landscape converted from lowland forest to rubber and oil palm plantations, Biogeosciences, 12, 5831-5852, https://doi.org/10.5194/bg-125831-2015, 2015.

Hassler, E., Corre, M. D., Kurniawan, S., and Veldkamp, E.: Soil nitrogen oxide fluxes from lowland forests converted to smallholder rubber and oil palm plantations in Sumatra, Indonesia, Biogeosciences, 14, 2781-2798, https://doi.org/10.5194/bg-142781-2017, 2017.

Hawthorne, W. D.: Ecological profiles of Ghanaian forest trees, Tropical forestry papers 29, Oxford Forestry Institute, University of Oxford, Oxford, UK, 1995.

Hijmans, R. J., Cameron, S. E., Parra, J. L., Jones, P. G., and Jarvis, A.: Very high resolution interpolated climate surfaces for global land areas, Int. J. Climatol., 25, 1965-1978, https://doi.org/10.1002/joc.1276, 2005.
Huang, J., Golombeck, A., Prinn, R. G., Weiss, R. F., Fraser, P. J., Simmonds, P., Dlugokencky, E. J., Hall, B., Elkins, J., Steele, L. P., Langenfelds, R. L., Krummel, P. B., Dutton, G., and Porter, L.: Estimation of regional emissions of nitrous oxide from 1997 to 2005 using multinetwork measurements, a chemical transport model, and an inverse method, J. Geophys. Res.-Atmos., 113, 1-19, https://doi.org/10.1029/2007JD009381, 2008.

Iddris, N. A., Corre, M. D., Yemefack, M., van Straaten, O., and Veldkamp, E.: Replication Data for: Stem and soil nitrous oxide fluxes from rainforest and cacao agroforest on highly weathered soils in the Congo Basin, Göttingen Research Online/Data, V1, https://doi.org/10.25625/T2CGYM, 2020.

IUSS Working Group WRB: World Reference Base for Soil Resources 2014, update 2015 International soil classification system for naming soils and creating legends for soil maps, World Soil Resources Reports No. 106, FAO, Rome, 2015.

Jarvis, A., Reuter, H. I., Nelson, A., and Guevara, E.: Holefilled SRTM for the globe, Version 4. CGIAR-CSI SRTM $90 \mathrm{~m}$ Database, Int. Cent. Trop. Agric. Cali, Columbia, available at: http://srtm.csi.cgiar.org (last access: September 2017), 2008.

Kiese, R., Hewett, B., Graham, A., and Butterbach-Bahl, K.: Seasonal variability of $\mathrm{N}_{2} \mathrm{O}$ emissions and $\mathrm{CH}_{4}$ uptake by tropical rainforest soils of Queensland, Australia, Global Biogeochem. Cy., 17, 1043, https://doi.org/10.1029/2002gb002014, 2003.

Kim, D. G., Kirschbaum, M. U. F., and Beedy, T. L.: Carbon sequestration and net emissions of $\mathrm{CH}_{4}$ and $\mathrm{N}_{2} \mathrm{O}$ under agroforestry: Synthesizing available data and suggestions for future studies, Agr. Ecosyst. Environ., 226, 65-78, https://doi.org/10.1016/j.agee.2016.04.011, 2016a.

Kim, D.-G., Thomas, A. D., Pelster, D., Rosenstock, T. S., and Sanz-Cobena, A.: Greenhouse gas emissions from natural ecosystems and agricultural lands in sub-Saharan Africa: synthesis of available data and suggestions for further research, Biogeosciences, 13, 4789-4809, https://doi.org/10.5194/bg-134789-2016, 2016b.

Koehler, B., Corre, M. D., Veldkamp, E., Wullaert, H., and Wright, S. J.: Immediate and long-term nitrogen oxide emissions from tropical forest soils exposed to elevated nitrogen input, Glob. Change Biol., 15, 2049-2066, https://doi.org/10.1111/j.13652486.2008.01826.x, 2009.

Kotto, J. S., Moukam, A., Njomgang, R., Tiki-Manga, T., Tonye, J., Diaw, C., Gockowski, J., Hauser, S., Weise, S. F., Nwaga, D., Zapfack, L., Palm, C. A., Woomer, P., Gillison, A., Bignell, D., and Tondoh, J.: Alternatives to slash-and-burn in Indonesia: summary report \& synthesis of phase II in Cameroon, Nairobi, Kenya, 2002.

Kreuzwieser, J., Buchholz, J., and Rennenberg, H.: Emission of Methane and Nitrous Oxide by Australian Mangrove Ecosystems, Plant Biol., 5, 423-431, https://doi.org/10.1055/s-200342712, 2003.

Kroetsch, D. and Wang, C.: Particle size distribution, in: Soil Sampling and Methods of Analysis, 2nd Edn., 713-725, 2008.

Lenhart, K., Behrendt, T., Greiner, S., Steinkamp, J., Well, R., Giesemann, A., and Keppler, F.: Nitrous oxide effluxes from plants as a potentially important source to the atmosphere, New Phytol., 221, 1398-1408, https://doi.org/10.1111/nph.15455, 2019.

Machacova, K., Papen, H., Kreuzwieser, J., and Rennenberg, H.: Inundation strongly stimulates nitrous oxide emissions 
from stems of the upland tree Fagus sylvatica and the riparian tree Alnus glutinosa, Plant Soil, 364, 287-301, https://doi.org/10.1007/s11104-012-1359-4, 2013.

Machacova, K., Bäck, J., Vanhatalo, A., Halmeenmäki, E., Kolari, P., Mammarella, I., Pumpanen, J., Acosta, M., Urban, O., and Pihlatie, M.: Pinus sylvestris as a missing source of nitrous oxide and methane in boreal forest, Sci. Rep., 6, 1-8, https://doi.org/10.1038/srep23410, 2016.

Machacova, K., Maier, M., Svobodova, K., Lang, F., and Urban, O.: Cryptogamic stem covers may contribute to nitrous oxide consumption by mature beech trees, Sci. Rep.-UK, 7, 1-7, https://doi.org/10.1038/s41598-017-13781-7, 2017.

Machacova, K., Vainio, E., Urban, O., and Pihlatie, M.: Seasonal dynamics of stem $\mathrm{N}_{2} \mathrm{O}$ exchange follow the physiological activity of boreal trees, Nat. Commun., 10, 1-13, https://doi.org/10.1038/s41467-019-12976-y, 2019.

Matson, A. L., Corre, M. D., Langs, K., and Veldkamp, E.: Soil trace gas fluxes along orthogonal precipitation and soil fertility gradients in tropical lowland forests of Panama, Biogeosciences, 14, 3509-3524, https://doi.org/10.5194/bg-14-3509-2017, 2017.

McJannet, D., Fitch, P., Disher, M., and Wallace, J.: Measurements of transpiration in four tropical rainforest types of north Queensland, Australia, Hydrol. Process., 21, 3549-3564, https://doi.org/10.1002/hyp.6576, 2007.

Müller, A. K., Matson, A. L., Corre, M. D., and Veldkamp, E.: Soil $\mathrm{N}_{2} \mathrm{O}$ fluxes along an elevation gradient of tropical montane forests under experimental nitrogen and phosphorus addition, Front. Earth Sci., 3, 1-12, https://doi.org/10.3389/feart.2015.00066, 2015.

Neill, C., Steudler, P. A., Garcia-Montiel, D. C., Melillo, J. M., Feigl, B. J., Piccolo, M. C., and Cerri, C. C.: Rates and controls of nitrous oxide and nitric oxide emissions following conversion of forest to pasture in Rondônia, Nutr. Cycl. Agroecosys., 71, 1-15, https://doi.org/10.1007/s10705-004-0378-9, 2005.

O'Brien, J. J., Oberbauer, S. F., and Clark, D. B.: Whole tree xylem sap flow responses to multiple environmental variables in a wet tropical forest, Plant Cell Environ., 27, 551-567, https://doi.org/10.1111/j.1365-3040.2003.01160.x, 2004.

Palm, C. A., Alegre, J. C., Arevalo, L., Mutuo, P. K., Mosier, A. R., and Coe, R.: Nitrous oxide and methane fluxes in six different land use systems in the Peruvian Amazon, Global Biogeochem. Cy., 16, 1073, https://doi.org/10.1029/2001gb001855, 2002.

Pennock, D. J. and Corre, M. D.: Development and application of landform segmentation procedures, Soil Till. Res., 58, 151-162, https://doi.org/10.1016/S0167-1987(00)00165-3, 2001.

Powers, J. S., Corre, M. D., Twine, T. E., and Veldkamp, E.: Geographic bias of field observations of soil carbon stocks with tropical land-use changes precludes spatial extrapolation, P. Natl. Acad. Sci. USA, 108, 6318-6322, https://doi.org/10.1073/pnas.1016774108, 2011.

Purbopuspito, J., Veldkamp, E., Brumme, R., and Murdiyarso, D.: Trace gas fluxes and nitrogen cycling along an elevation sequence of tropical montane forests in Central Sulawesi, Indonesia, Global Biogeochem. Cy., 20, 1-11, https://doi.org/10.1029/2005GB002516, 2006.

R Core Team: R: A language and environment for statistical computing. R Foundation for Statistical Computing, Vienna, Austria, 2018.
Ravishankara, A. R., Daniel, J. S., and Portmann, R. W.: Nitrous oxide $\left(\mathrm{N}_{2} \mathrm{O}\right)$ : The dominant ozone-depleting substance emitted in the 21st century, Science, 326, 123-125, https://doi.org/10.1126/science.1176985, 2009.

Rusch, H. and Rennenberg, H.: Black alder (Alnus glutinosa (L.) Gaertn.) trees mediate methane and nitrous oxide emission from the soil to the atmosphere, Plant Soil, 201, 1-7, https://doi.org/10.1023/A:1004331521059, 1998.

Saj, S., Jagoret, P., and Todem Ngogue, H.: Carbon storage and density dynamics of associated trees in three contrasting Theobroma cacao agroforests of Central Cameroon, Agroforest. Syst., 87, 1309-1320, https://doi.org/10.1007/s10457-013-9639-4, 2013.

Serca, D., Delmas, R., Jambert, C., and Labroue, L.: Emissions of nitrogen oxides from equatorial rain forest in central Africa, Tellus B, 46, 243-254, https://doi.org/10.3402/tellusb.v46i4.15795, 1994.

Silver, W. L., Neff, J., McGroddy, M., Veldkamp, E., Keller, M., and Cosme, R.: Effects of Soil Texture on Belowground Carbon and Nutrient Storage in a Lowland Amazonian Forest Ecosystem, Ecosystems, 3, 193-209, https://doi.org/10.1007/s100210000019, 2000.

Sonwa, D. J., Nkongmeneck, B. A., Weise, S. F., Tchatat, M., Adesina, A. A., and Janssens, M. J. J.: Diversity of plants in cocoa agroforests in the humid forest zone of Southern Cameroon, Biodivers. Conserv., 16, 2385-2400, https://doi.org/10.1007/s10531-007-9187-1, 2007.

Tchiofo Lontsi, R., Corre, M. D., van Straaten, O., and Veldkamp, E.: Changes in soil organic carbon and nutrient stocks in conventional selective logging versus reducedimpact logging in rainforests on highly weathered soils in Southern Cameroon, Forest Ecol. Manage., 451, 117522, https://doi.org/10.1016/j.foreco.2019.117522, 2019.

Thompson, R. L., Chevallier, F., Crotwell, A. M., Dutton, G., Langenfelds, R. L., Prinn, R. G., Weiss, R. F., Tohjima, Y., Nakazawa, T., Krummel, P. B., Steele, L. P., Fraser, P., O'Doherty, S., Ishijima, K., and Aoki, S.: Nitrous oxide emissions 1999 to 2009 from a global atmospheric inversion, Atmos. Chem. Phys., 14, 1801-1817, https://doi.org/10.5194/acp14-1801-2014, 2014.

Valentini, R., Arneth, A., Bombelli, A., Castaldi, S., Cazzolla Gatti, R., Chevallier, F., Ciais, P., Grieco, E., Hartmann, J., Henry, M., Houghton, R. A., Jung, M., Kutsch, W. L., Malhi, Y., Mayorga, E., Merbold, L., Murray-Tortarolo, G., Papale, D., Peylin, P., Poulter, B., Raymond, P. A., Santini, M., Sitch, S., Vaglio Laurin, G., van der Werf, G. R., Williams, C. A., and Scholes, R. J.: A full greenhouse gases budget of Africa: synthesis, uncertainties, and vulnerabilities, Biogeosciences, 11, 381-407, https://doi.org/10.5194/bg-11-381-2014, 2014.

van Lent, J., Hergoualc'h, K., and Verchot, L. V.: Reviews and syntheses: Soil $\mathrm{N}_{2} \mathrm{O}$ and $\mathrm{NO}$ emissions from land use and land-use change in the tropics and subtropics: a meta-analysis, Biogeosciences, 12, 7299-7313, https://doi.org/10.5194/bg-127299-2015, 2015.

van Straaten, O., Corre, M. D., Wolf, K., Tchienkoua, M., Cuellar, E., Matthews, R. B., and Veldkamp, E.: Conversion of lowland tropical forests to tree cash crop plantations loses up to onehalf of stored soil organic carbon, P. Natl. Acad. Sci. USA, 112, 9956-9960, https://doi.org/10.1073/pnas.1504628112, 2015. 
Veldkamp, E.: Organic Carbon Turnover in Three Tropical Soils under Pasture after Deforestation, Soil Sci. Soc. Am. J., 58, 175-180, https://doi.org/10.2136/sssaj1994.03615995005800010025x, 1994.

Veldkamp, E., Purbopuspito, J., Corre, M. D., Brumme, R., and Murdiyarso, D.: Land use change effects on trace gas fluxes in the forest margins of Central Sulawesi, Indonesia, J. Geophys. Res.Biogeo., 113, 1-11, https://doi.org/10.1029/2007JG000522, 2008.

Veldkamp, E., Koehler, B., and Corre, M. D.: Indications of nitrogen-limited methane uptake in tropical forest soils, Biogeosciences, 10, 5367-5379, https://doi.org/10.5194/bg-10-53672013, 2013.

Veldkamp, E., Schmidt, M., Powers, J. S., and Corre, M. D.: Deforestation and reforestation impacts on soils in the tropics, Nat. Rev. Earth Environ., 1, 590-605, https://doi.org/10.1038/s43017020-0091-5, 2020.

Verchot, L. V., Hutabarat, L., Hairiah, K., and van Noordwijk, M.: Nitrogen availability and soil $\mathrm{N}_{2} \mathrm{O}$ emissions following conversion of forests to coffee in southern Sumatra, Global Biogeochem. Cy., 20, 1-12, https://doi.org/10.1029/2005GB002469, 2006.

Wanyama, I., Pelster, D. E., Arias-Navarro, C., ButterbachBahl, K., Verchot, L. V., and Rufino, M. C.: Management intensity controls soil $\mathrm{N}_{2} \mathrm{O}$ fluxes in an Afromontane ecosystem, Sci. Total Environ., 624, 769-780, https://doi.org/10.1016/j.scitotenv.2017.12.081, 2018.

Welch, B., Gauci, V., and Sayer, E. J.: Tree stem bases are sources of $\mathrm{CH}_{4}$ and $\mathrm{N}_{2} \mathrm{O}$ in a tropical forest on upland soil during the dry to wet season transition, Glob. Change Biol., 25, 361-372, https://doi.org/10.1111/gcb.14498, 2019.
Wen, Y., Corre, M. D., Rachow, C., Chen, L., and Veldkamp, E.: Nitrous oxide emissions from stems of alder, beech and spruce in a temperate forest, Plant Soil, 420, 423-434, https://doi.org/10.1007/s11104-017-3416-5, 2017.

Werner, C., Zheng, X., Tang, J., Xie, B., Liu, C., Kiese, R., and Butterbach-Bahl, K.: $\mathrm{N}_{2} \mathrm{O}, \mathrm{CH}_{4}$ and $\mathrm{CO}_{2}$ emissions from seasonal tropical rainforests and a rubber plantation in Southwest China, Plant Soil, 289, 335-353, https://doi.org/10.1007/s11104006-9143-y, 2006.

Werner, C., Butterbach-Bahl, K., Haas, E., Hickler, T., and Kiese, R.: A global inventory of $\mathrm{N}_{2} \mathrm{O}$ emissions from tropical rainforest soils using a detailed biogeochemical model, Global Biogeochem. Cy., 21, GB3010, https://doi.org/10.1029/2006GB002909, 2007a.

Werner, C., Kiese, R., and Butterbach-Bahl, K.: Soil-atmosphere exchange of $\mathrm{N}_{2} \mathrm{O}, \mathrm{CH}_{4}$, and $\mathrm{CO}_{2}$ and controlling environmental factors for tropical rain forest sites in western Kenya, J. Geophys. Res., 112, D03308, https://doi.org/10.1029/2006JD007388, $2007 b$.

Wolf, K., Veldkamp, E., Homeier, J., and Martinson, G. O.: Nitrogen availability links forest productivity, soil nitrous oxide and nitric oxide fluxes of a tropical montane forest in southern Ecuador, Global Biogeochem. Cy., 25, GB4009, https://doi.org/10.1029/2010GB003876, 2011.

Zanne, A. E., Lopez-Gonzalez, G., Coomes, David A., Ilic, J., Jansen, S., Lewis, S. L., Miller, R. B., Swenson, N. G., Wiemann, M. C., and Chave, J.: Data from: Towards a worldwide wood economics spectrum, v5, Dryad, Dataset, https://doi.org/10.5061/dryad.234, 2009.

Zapfack, L., Engwald, S., Sonké, B., Achoundong, G., and Madong, B. A.: The impact of land conversion on plant biodiversity in the forest zone of Cameroon, Biodivers. Conserv., 11, 2047-2061, https://doi.org/10.1023/A:1020861925294, 2002. 